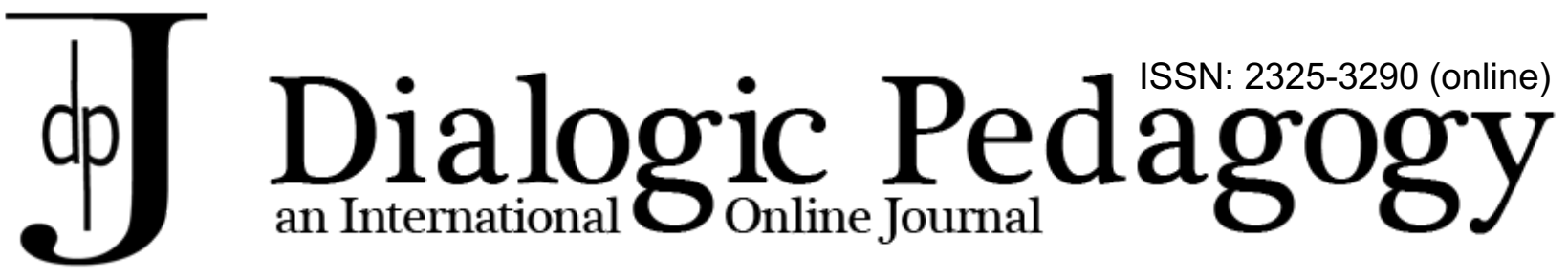

\title{
The University of Students: A place for joint self-education
}

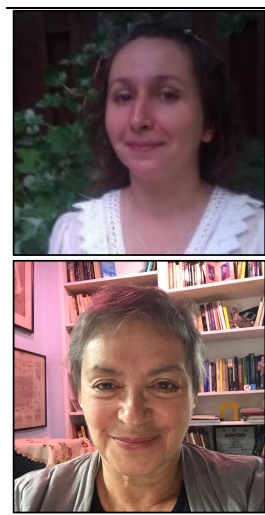

Olga Shugurova

University of Manitoba, CA

Ana Marjanovic-Shane

Independent Scholar, USA

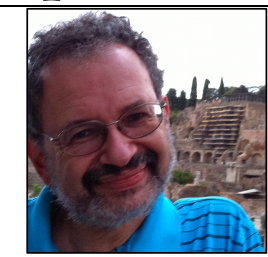

Eugene Matusov

University of Delaware, USA

\begin{abstract}
In this article, we explain, explore, and problematize the formation, organization, leadership, and daily educational life of the first (to our knowledge) international democratic university of students (UniS) in the 21st century. UniS is run by the students, for the students, and with the students for their diverse purposes, desires, interests, and needs. A student is anyone who freely chooses to study something for whatever reason. Everyone can become a student at any time without any high school credits, fees, bureaucracy, tests, or any other form of human suffering. But what exactly is UniS? Why students? What if...? How can one visualize UniS, which is "so vague, so bizarre, so unnecessary to me!" What are its philosophical principles? Who are we? What does the University of Students look like? In the spirit of curiosity, wonder, leisure, fun, freedom, and love for learning, we invite the reader to attend and connect with two working edu-clubs of UniS: a movie club "Schooling Around the World and Time" and an "Educationalist Club." In addition, we discuss some of the main issues, limitations, and challenges, including the civilization of the necessities, colonization of the human spirit by the economy, a lack of genuine leisure, and toxification of the human by foisted education. The open-ended, poetic conclusion lets the readers form their own interpretations, ideas, questions, and answers about UniS. What is the future of UniS? And only time will tell, 10, 100 years later or 100 light-years from now.
\end{abstract}

Keywords: University of Students, international, democratic student-led university, democratic higher education, joint self-education, self-realization, freedom

Acknowledgment: We are thankful to all members of the University of Students and especially its organizers: Artyom Fyodorov, Viktor Perminov, Tatyana Yastrebova, Abram De Bryun, and Alina Sharova. Thanks to Ann Qui, Tara Ratnam, Tina Kullenberg, and Bob Hampel for their feedback, editing, and comments on the early versions of the manuscript. Some of these comments are included in the manuscript on the margins.

Olga Shugurova graduated with a Ph.D. from the Schulich School of Education at Nipissing University in 2017. Her arts-based research focus was on a cultural and historical context of learning without schooling. Since 2015, Olga has been teaching as a sessional and distance course instructor in the Faculty of Arts and Education at the University of Manitoba. During this time, she has developed a keen interest in dialogic 
pedagogy in teacher education and interdisciplinary learning environments. Her current research focus is on innovative, creative dialogic pedagogy of freedom and education as art.

Eugene Matusov is a Professor of Education at the University of Delaware. He studied developmental psychology with Soviet researchers working in the Vygotskian paradigm and worked as a schoolteacher before immigrating to the United States. He uses sociocultural and Bakhtinian dialogic approaches to education. His recent books are: Matusov, E. (2017). Nikolai N. Konstantinov's authorial math pedagogy for people with wings, Matusov, E. \& Brobst, J. (2013). Radical experiment in dialogic pedagogy in higher education and its Centauric failure: Chronotopic analysis, and Matusov, E. (2009). Journey into dialogic pedagogy.

Ana Marjanovic-Shane is an Independent Scholar interested in ethical ontological dialogism and meaning making in education, democratic education, students' academic freedoms and students' critical and creative authorship in self-education. Her articles in English and Serbian were published in various journals (e.g. Mind, Culture, Activity Journal, Learning, Culture and Social Interaction, Dialogic Pedagogy Journal) and as book chapters in books on play and education. Two recent publications include: Marjanovic-Shane, A., Meacham, S., Choi, H. J., Lopez, S., \& Matusov, E. (2019). Idea-dying in critical ontological pedagogical dialogue. Learning, Culture and Social Interaction, 20,68-79, and Matusov, E., A. Marjanovic-Shane \& M. Gradovski, (2019). Dialogic pedagogy and polyphonic research art: Bakhtin by and for educators, Palgrave Macmillan. Ana lives and works in the USA.

\section{Introduction}

Question: University of who?!

Answer: Students.

Q: Why "students"?

A: Because in the University of Students, it is the students who decide whether to study, what to study, how to study, why to study, when to study, with whom, what is education, and so on.

Q: But how do you decide the learning program (the curriculum) for your students?

A: "We," the organizers of the University of Students, don't. Students decide for themselves what to study based on their wants and needs defined by themselves.

Q: Hmmm. What if the students do not want to study anything?

A: Then they are not students. We define students as those who want and/or need to study something. Also, they are aware of their desire and need, and they are ready to commit themselves. Of course, some people may join the University of Students as potential students to explore if something in the University will attract or spark their desire to study. Potential students are welcomed. What is not welcomed, however, is foisted education - education against the student's will.

Q: What if a student has only a very slight idea of what they want to study? How can this student decide what to study and how to study it? Isn't it like "the blind leading the blind"? Will the students leading themselves "fall all into a pit" of ignorance?

\footnotetext{
${ }^{1}$ Reference to the idiom and metaphor with a long and diverse history with multiple roots: https://en.wikipedia.org/wiki/The_blind_leading_the_blind
} 
A: A student can ask for help from their peers, or us (or somebody else) for advice, or seek the help of a teacher. A student also can wait until a particular educational club or a specific onetime educational event resonates with them.

Q: What if a student does not know that they need some guidance or help? What if a student does not know what kind of guidance they need?

A: Good question. But who else will know or notice that the student needs some help? If it is the teacher, whom the student chose in the first place, expressing their trust in this teacher. The teacher might want to share their observation or concern with the student, since the student has expressed their trust in this teacher by choosing the teacher. If it were a peer, again the peer can share the observation or concern. Of course, it is up to the student to accept or reject the observation and offered help by the teacher or the peer. Alternatively, a student may wait longer until they realize a need for guidance. The University of Students provides a space for students to explore possibilities and seek guidance if they want/need it, to discover or formulate their own learning interests, desires and needs.

Q: How do you credit students who successfully learned something or successfully accomplished a course? How can an employer trust that your graduates have been successfully educated?

A: We don't provide any credentials. The University of Students is not a certifying or accrediting body. However, if a student needs to receive a credential, they can search for an appropriate agency that provides such a credential. The University organizers, or peers, or teachers can help such students find these agencies if a student needs this help. As to the employers, we think that assessing job candidates' competence is their responsibility, not ours.

Actually, we think that the job candidates' educational background and history should be irrelevant for the assessment of their competence. Who cares how and where a job candidate acquires a skill or knowledge or experience or competence? - The only thing that matters is that the job candidate is competent and ready for the job now, according to the employer.

Q: So, your University of Students is a kind of prep school, isn't it?

A: Not necessarily. It can be a "prep school" for those students who want to prepare for getting credits. But for the students who are not interested in getting credits, it is not a "prep school." People can pursue their own interests, curiosities, passions, socialization in desired communities of practice, critical examinations, needs, and wonders. They can stay in the University of Students forever if they wish to do so.

Q: Can a teacher join your University?

A: Yes, if this teacher finds students who want to study with them. The students' conditional consent for having a teacher who provides guidance is what defines the teacher role - be so a stable and well-defined role or a dynamic, interchangeable, and fuzzy one.

Q: In this case, why is the University of Students needed at all? Any person can study whatever they want to study without any university! Why is it needed? What for?

A: True. However, some self-directed students may want to study in a group with peers. Some other self-directed students may need a teacher. Other students may need advice or a short- or long-term adviser who may help the students to figure out what they want to study, how, what 
for, and with whom. Some students may need somebody who will push them to study - what we call "autopaternalism" (see below). Some students may want to develop a hybrid of these well-defined types of studies or a dynamic mixture of their ill-defined types. The University of Students is an educational social media that helps students find each other, teachers, and advisors all over the world.

Q: Why do you call this medium "university" and not "school"?

A: Conventional schools are defined by learning programs imposed on the students. Definitely, we are not defined by the imposed curriculum.

In contrast, the Greek original word "school" literally meant "leisure," -- education as a form of leisure. Students' self-education at the University of Students can be a form of leisure, but also it can be a form of a necessity for some students.

We like the term "university" because it reflects the Vastness, Interconnectedness, Diversity, and Infinity of The Universe of the educational aspirations of the students. Q: Sorry, but I still cannot visualize your "University of Students"! It sounds so vague, so bizarre, so unnecessary to me.

A: The University of Students IS unnecessary like art and play are "unnecessary," while at the same time, humans existentially crave for art and play. We believe that people's existential craving for the University of Students emerges when the life necessities get more or less satisfied. But we can be wrong...

Please read the rest of this article - we hope it will help you to clarify your understanding of the University of Students and raise new questions.

Q: But for whom is your article? Who is your targeted audience? Potential students? Is it advocacy for your University for people to enroll? What is the purpose of this long manuscript?

A: Of course, we cannot predict by whom and how our word will be responded ${ }^{2}$. Our goal here is to provide an academic reflection on a fly - a dialogic analysis - of the historically given and emerging phenomenon of the University of Students enterprise, in which we have been involved. We are trying to comprehend for ourselves what we are doing, why, what its values are, what our challenges are, what attracts us to it, what our historical roots are. Our goal is to engage in a critical dialogue rather than to persuade. We want to start a reflective dialogue - dialogue-agreement and dialogue-disagreement - with whoever is interested. In this sense, this is NOT an enrollment pamphlet, but we do not mind if it may have this function for some readers.

\section{What is the University of Students? Our Manifesto}

The University of Students (UniS) is the first ${ }^{3}$ democratic, international university in the world that is run by the students, for the students, and with the students for their diverse purposes, desires, interests, and needs. A student is anyone who freely chooses to study something for whatever reason. Everyone can become a student at any time without any high school credits, fees, bureaucracy, tests, or any other form of human suffering. The concept of a "student" is very broad, creative, fluent, and self-determined without a specific presupposed label; it is personal and powerful. To become a student, a person should have a unique, self-authored idea: "Oh, I have an idea...! I would like to explore it, venture into it, develop it...." "Oh, there is something I have always wanted to learn but never had a chance." "Oh, I wonder!"

${ }^{2}$ This is a paraphrase from a poem by the famous Russian poet Fyodor Tyutchev, written in 1869: https://ruverses.com/fyodortyutchev/we-can-not-divine/8631/

${ }^{3}$ The question of how first our university is can be contested - see our historical section below. 
Alternatively, a student may need, rather than want, to study something. "Or, I have to study this because it will help me to get from point A to point B in my life." In any case, it is a student's choice.

UniS is an educational Wonderland; it is a different worldview through a looking glass of freedom, curiosity, wonder, socialization in the desired communities of practice (Lave, 1992; Wenger, 1998), critical examination of the self, life, world, and society (cf. Socrates, Apology ${ }^{4}$ ), or need. At UniS, everything is possible to imagine and, therefore, to learn. Everyone is welcome, all the time, without any hierarchical gatekeepers (unless a student requires this hierarchy from the authority of the student's own choice). There are infinite possibilities of becoming a student at UniS. Basically, it is up to each person how to define themselves as students and how to design their learning. At UniS, students are the leaders and authors of their learning.

Everybody interested in their self-education is welcome to become a member of the University of Students regardless of their age, place of living, or educational interests. UniS promotes students' encounters and dialogues through edu-clubs, one-time events, and other educational forms, organized by the students, where students are the leaders of their own learning. There are no pre-planned courses, learning programs, assignments, exams, grades, credits, diplomas, units, periods, terms, bureaucracy. A particular edu-club or teacher may want to charge students a fee or tuition but not UniS itself. UniS students author all aspects of their self-education whether this is completely self-directed, peer-directed, or trusting expert/teacher support, or autopaternalistic, or any imaginative combination they find meaningful. UniS is not about credentials, standards, preset curricula, exams, teacher assignments, or teachers.

At the same time, a teacher or anyone else can offer students a preplanned or an emergent course, a talk, workshop, etc. at the University of Students. However, it is up to the students themselves to accept this course and the teacher's requirements or reject them at any time.

UniS is a new post-scarcity, post-credential, post-institutional socio-educational media where students study what they want or need, how they want, and with whomever they want. UniS with its planetary-scale and diverse, multilingual, international student body responds to the current social, economic, cultural, geopolitical, and environmental challenges. The recent Covid-19 pandemic has created a world of increasing uncertainty, vulnerabilities, and unknowns. And it has also shown new ways, forms, and possibilities of education. Most importantly, it has opened, more than anything else, a glimpse into the promises and possibilities of self-education.

UniS is its students in the dialogic encounter. We believe that the age of information - the age in which education is understood as acquiring knowledge and skills preset by society, the age of information scarcity and inaccessibility, the age of foisted education - is almost behind us (we hope!). The age of selfeducation is coming. UniS takes students' self-education to the next evolutionary level of social media as educational media (socio-educational media) - the Digital Agora, where people can come and go, encounter each other on purpose or by chance, for educational and other purposes. The socio-educational media allows people to develop their own self-studies, find, and invite other people who want to join them. UniS offers the first, one-of-a-kind, socio-educational media space. People from all walks of life participate in a leisurely inquiry in search of self-actualization, self-realization, imagination, creativity, critical examination, and self-determination. They author their life, their education, and their future in the increasingly unknown and uncertain world pregnant with new challenges and new exciting possibilities.

\footnotetext{
4 "The unexamined life is not worth living."
} 


\section{The philosophical principles of the University of Students}

The University of Students is based on the following several philosophical principles: self-education (in contrast to Kantian educational paternalism of foisted education), negative freedom (in contrast to positive freedom), student-trusted guidance (in contrast to imposed guidance), dialogic encounter (in contrast to monologic transmission or inducing knowledge and skills), and Agora (in contrast to the sterile on-task educational environment).

\section{Self-education}

Philosophers of the Enlightenment, most notably Jacques Jean Rousseau, Immanuel Kant, and Johann Gottlieb Fichte, probably for the first time in human history articulated and justified the need for universal foisted education based on the philosophical principle of educational paternalism (Berlin \& Hardy, 2002). Ironically, they justified the need for foisted education through the Enlightenment recognition and prioritization of human dignity, freedom, and autonomy in their struggle against the authority of the Church and King. They argued that people are dignified only when they are free and autonomous to make all decisions about their own life. However, there was a caveat there. Not all people deserve their full autonomy but only those who are reasonable, rational, well-informed, knowledgeable, sounded, responsible, selfcontrolled, and well-intended. Left on its own device, irresponsible, unreasonable, irrational, ill-informed, ignorant, unsounded, impulsive, immature, and ill-intended autonomy leads to disaster. The autonomous device of people must be formed first, and only then people can be and must be granted their dignity of autonomy. Since, according to Kant, the moral, epistemological, and aesthetic truth is universal, all reasonable, rational, well-informed, knowledgeable, sound, responsible, and well-intended people will eventually reach a consensus when they are given the autonomy and freedom to explore truth by themselves. Even more, a growing agreement among those reasonable people provides a proxy for the universal truth. The more reasonable people become, the more mutually replaceable they are, bound by the universal truth.

According to these philosophers of the Enlightenment, there are two major obstacles to human dignity, rooted in the phenomenon of "tutelage." "Tutelage is man's inability to make use of his understanding without direction from another" (Kant, 1784). One is external tutelage: political oppression that has to be remedied by political means. The other one is internal ("self-incurred tutelage"): personal ignorance that must be cured by institutional education imposed on the ignorant masses by the State.

In his famous 1784 treatise "An answer to the question: What is Enlightenment?", Kant argued that foisted education has to be designed carefully to give the students, forced to education, the freedom to reveal, exercise, and explore their imperfect reason, emerging rationality, misconceptions, and ingrained ignorance. According to Kant, the teacher must not force the truth on the students (except in religious education) but carefully guide them toward the universal truth through a public dialogic exploration of the students' errors and shortcomings. The teacher's power of persuasion must be based not on their epistemological or institutional authority, nor a system of rewards and punishment, nor on brutal force but rather on the power of reason, rationality, and the universality of the truth. Only through this self-persuasive process of the students' free exploration of their own imperfect reasoning, rationality, and knowledge, argued Kant, can the students' own rational device be formed.

In foisted education, continued Kant, the students must have the freedom to reason, however imperfectly it might be, but not the freedom from reason. The curriculum and education itself must be carefully chosen and then forcefully imposed on the students by reasonable and knowledgeable people through the power of the State. Fichte argued that "compulsion is also a kind of education" (cited in Berlin \& Hardy, 2002). 
However, Rousseau (1979) insisted that good education must make compulsion invisible to the student. The student should be manipulated by a skillful teacher into an illusion that their education is voluntary: the student should want what the teacher wants them to want. Rousseau advised a teacher, "Take the opposite course with your pupil; let him always think he is master while you are really master..... No doubt he ought only to do what he wants, but he ought to want to do nothing but what you want him to do. He should never take a step you have not foreseen, nor utter a word you could not foretell (Rousseau, 1979 , p. 120, the italics ours).

The instruction, argued Kant and Rousseau, has to be co-constructed by the students' imperfect reason and the teacher's pedagogical mastery to reveal to the students their own shortcomings. Kant criticized the conventional education of his time, which can be also applied to the conventional institutional education of the modern time, which imposes truth and correctness on the students at any price.

At this point, these Enlightenment philosophers articulated the principles of the Progressive Education (Matusov, 2021a): educational paternalism, imposed curriculum and education, but also coconstructed guidance, and the freedom of students' reason. The Enlightenment saw the panacea to all personal shortcomings and societal ills in education after the political oppression is resolved, while ignorance remains the root of all problems. Elsewhere Matusov (2020d) criticized this Enlightenment project for robbing people of their agency and making them slaves of natural laws and rationalism.

Conversely, education is self-education (Gadamer, 2001). Education differs from learning because for learning to become transformed into education, it must be positively appraised by the learner; the learner must make an authorial appraising, a judgment about their learning or insight/satori (Matusov, 2021b). That is why genuine education is always self-education.

The philosophical principle of self-education is based on the notions of radical pluralism, contextualism, and unique authorial agency. According to the notion of radical pluralism introduced by the Jewish-Russian-British philosopher Isaiah Berlin, human values and virtues often cannot be fully known and united harmoniously in one non-contradictory principle:

... [Berlin's radical pluralism] rejects the [monist] view that all conflicts of values can be finally resolved by synthesis and that all desirable goals may be reconciled. It recognises that human nature is such that it generates values which, though equally sacred, equally ultimate, exclude one another, without there being any possibility of establishing an objective hierarchical relation between them. Moral conduct therefore may involve making agonising choices, without the help of universal criteria, between incompatible but equally desirable values (Kelly, 1978, p. xv).

A person morally defines themselves of what kind of person they are by how they judge, act upon, prioritize, and make "agonizing choices" about competing and often irreconcilable values and virtues in a given unique situation in their own unique authorial way and how this person responds to the challenges of other people and their own about their authorial judgments, deeds, agonizing choices, and prioritizations.

From this philosophical perspective of radical pluralism, education is another unique, personal, authorial endeavor - another deed - that a person embraces, taking responsibility for themselves. That is why education is always a personal, unique, and authorial act. Genuine education is always self-education. Although society - economy, governance, state, citizenship, democratic participation, health care, welfare, nationalism, patriotism, military, local communities, family, etc., - can benefit from a person's selfeducation, society cannot legitimately take over, define, impose, and control a person's education. Society 
can legitimately dictate its needs to a person, but it is up to the person how to respond to these needs and the dictates through their own self-education (or not respond at all).

But what is (self-)education? What are its goals, content, and quality?

This is a tricky question. We cannot answer it for other people. As soon as we define education for other people, we will kill genuine education, self-education. Defining education is the sole prerogative of the author of their own self-education - namely, a student. One student in a given situation may define their own education as solving a particular problem they faced in their life. Another student may define their own education as passing the SAT to enter a college of their choice or getting a driving license. A third student may define their own education as learning a musical instrument to enjoy playing it. A fourth student may define their own education as acquiring a particular profession or vocation. A fifth student may define their own education as addressing their own curiosity, puzzlement, and interest about the social or natural world and/or the self. A sixth student may define their own education as a particular form of leisure for their self-

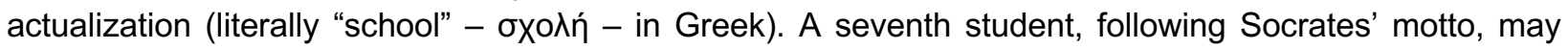
define education as a life-long commitment to critically examine the self, life, society, world (and education itself). And so on and so forth - people creatively define their self-education. They can switch from one type of definition to another or combine them at times. The University of Students does not define education for its students but rather facilitates the students' self-education and its pursuit.

At the same time, self-education is not necessarily equal to the autodidact, when the student defines and organizes their own education solely, without the involvement of other people. An autodidact is a form of self-education but there are other forms. Matusov (2022, submitted) has abstracted, at least, five major forms of self-education, including the autodidact. The second form is the symdidact of studying together with more or less equal peers. The third form of self-education is the autodidact with advisement, when the student asks a trusted person for advice about their own self-education. These three forms of self-education are more or less self-directed. The following two are not. That is why we do not equate selfeducation with "free education," or "democratic education," or "self-directed education."

The fourth form of self-education is the odigósdidact - studying under the direction and guidance of a trusted teacher while the student remains the final authority for their own education. Finally, the fifth, and probably the most controversial, form of self-education is a student's autopaternalism, when the student demands a trusted person (e.g., a teacher) to force and motivate them to study what the student wants to study. Matusov argues that a student can combine or dynamically move from one form of their own selfeducation to another. In self-education, all relationships of trust are conditional: as soon as the educatee stops their trust, their relations with the advisor or teacher will legitimately stop. This is how self-education is different from foisted education. The University of Students aims at creating possibilities for diverse forms of self-education defined and chosen by the students.

\section{Negative freedom}

Self-education is based on a premise of a human right to have freedom - a bubble of sovereignty, autonomy, and privacy - in the sense of what Isaiah Berlin called, "negative freedom." In this bubble of negative freedom, the student has a legitimate right to define and practice their own self-education without asking permission from any educational authority or peers. This bubble of personal negative freedom can be quite limited and even suffocatingly small, or, alternatively, it can be very big. In any case, within the bubble, a student can think, speak, and act without any interference and domination of asking permission or need to coordinate with someone else (Pettit, 2014). 
Berlin defined "negative freedom" as that "area within which the subject - a person or group of persons - is or should be left to do or be what he is able to do or be, without interference by other persons" (Berlin, 2017, p. 34). Negative liberty is about the boundaries of a person's sovereignty and privacy, within which no one else has a right [to interfere and] to define for this person what to be, do, or think. Unless something is prohibited by the law, whatever the person desires, does, says, or thinks is their own business. Negative freedom is "freedom from" (Marjanovic-Shane, 2022, in press-a).

Self-education belongs to this sphere of personal negative freedom. It means personal negative freedom and the right to decide all aspects of one's own education including whether to participate, how to participate in the educational activities and to judge whether and to what extent these activities are personally meaningful and/or useful (Matusov, 2020c, 2020d).

The University of Students (UniS) offers the protection and assurance of self-education and personal negative freedom of making all educational decisions and evaluations. The primary educational negative freedom is for the student to define their own education, whether they want to engage in education or not, what to study, how to study, with whom, when, where, under what conditions, and so on. The student may or may not make all these decisions by themselves, but, in any way, we insist that the student remains the highest authority of their own education at any time. This is why the University of Students delegates all educational and organizational questions to the students themselves. For example, students can decide themselves if they want to charge a tuition fee for their educational clubs or courses or whether they want to have teachers or not. Teachers can design and announce their courses to potential students in the way they like to run, except to impose the curriculum or instruction without the students' consent - always a conditional consent that each student can withdraw at any time.

In contrast, conventional institutional foisted education and even many innovative (usually progressive) instructional foisted education rely on the concept of positive freedom, "freedom toward." Conventional institutional foisted education channels the students' freedom toward the successful acquisition of the pre-set knowledge and skills that society wants them to have. Innovative progressive institutional foisted education channels the students' desires and motivation toward studies of the curriculum (in a broader sense) desired by the society or the teachers. In both cases, education is based on the non-negotiable imposition of education, the definition of education, curriculum, instruction, and organization of the education on the students (Matusov, 2015). When students have their own initiatives and desires, they must ask the educational authorities for permission to enact their own initiatives and desires (cf. the notion of domination, Pettit, 2014).

\section{Student-entrusted guidance by others}

Except in the autodidact form of self-education, where the students themselves find and define selfdirected guidance, all other forms of self-education are based on the student-entrusted guidance provided by other people: peers, advisors, and teachers. Matusov (2022, submitted) argues that student-entrusted guidance is based on the guide's fiduciary duty to the student (the beneficiary). He unpackages the fiduciary responsibility in education by the following list:

1. The [student] is bonded with the [guide] by the relationship of trust, good faith, safety, candor, and fairness (Grierson, 2018; Rumel, 2013).

2. The [guide] promises to provide help and act in the best interests of the [student]. "The fiduciary [guide] must forsake all self-interest and conflict of interest, and the making of secret profit in performance of the duties" (Grierson, 2018, p. 205)

3. The [student] is recognized by the [guide] as the highest authority to define their own best interests and act upon them.

4. However, the [student] does not always know well what their best interests are because of a lack of information about alternatives or because of having blind spots. When it is the case, the [guide] must inform 


\begin{abstract}
the [student] and help [the student] find out their best interests, at the best of the [guide]'s ability and competence.

5. The [guide] must search for and learn about the limitations of their abilities and competence and, when needed, direct the [student] to others for help.

6. The fiduciary relationship is consensual, initiated by the [student]. It can be terminated by the [student] or by the [guide] at any time for any reason.

... The biggest tension among the items is between items \#3 and \#4. While item \#3 affirms the primacy of the beneficiary (e.g., student) over the fiduciary (e.g., teacher) in defining their best interests and acting upon them, item \#4 entrusts the [guide] with freedom, authorship, activism, and responsibility to inform the [student] about alternatives and issues unknown or invisible to them. Item \#4 assures that the [the guide] is not a "slave" of the [student] to follow their potentially uninformed and even harmful desires. At the same time, the [student] remains in charge of accepting or rejecting the new alternatives and visions presented or induced by the [guide], including acceptance or rejection of the entire guidance initiated by the [guide]. In some cases, the [student]'s rejection of the [guide]'s guidance might lead to a breakdown of their consensual relationship (item\#6) (Matusov, 2022, submitted).
\end{abstract}

Facilitation of the students' self-education can take many different paths and forms. The UniS mission is to:

a) Create opportunities for the students' encounters with other students;

b) Help connect students with experts in their areas of interest (who are open to teaching at UniS);

c) Organize critical dialogues that can help students discover and define their desires, interests, next steps, etc.;

What else?

\title{
Dialogic encounter of unmergeable consciousnesses with equal rights
}

The heart of the University of Students is a dialogic encounter of students. A Russian philosopher of dialogism Mikhail Bakhtin ${ }^{5}$ defined the dialogic encounter as an event of a meeting of unmergeable never fully transparent to each other - consciousnesses with equal rights, " $\boldsymbol{A}$ plurality of independent and unmerged voices and consciousnesses, a genuine polyphony of fully valid voices is in fact the chief characteristic of [a dialogic encounter]. What unfolds in [in a dialogic encounter] is ... a plurality of consciousnesses, with equal rights and each with its own world, combine but are not merged in the unity of the event [co-being, transformative being together] (Bakhtin, 1999, p. 6; the italics original, the bold ours). Matusov and Marjanovic-Shane (2015) have abstracted at least three types of dialogic encounter in education: 1) an agonistic encounter of frenemies, 2) an encounter of strangers for authorial self-growth, and 3) a hanging-out encounter of friends.

An agonistic encounter of frenemies

Based on the work of a Belgian political theorist Chantal Mouffe (2000), Matusov and MarjanovicShane (2015) described an agonistic dialogic as transformation of hostile, antagonistic relationships of enemies, based on paradigmatic, irreconcilable differences, and competition for power, into an agonistic relationship of appreciation the differences "as a potential source for one's own unknown self-limitation of truths and values" (Matusov \& Marjanovic-Shane, 2015, p. 211). Whereas the Enlightenment project seeks ways of eliminating violence, power imposition, authority, hegemony, antagonism, and politics from human life through deliberative rationality (cf. Habermas), Mouffe argues that the aim of democracy is to "limit and

${ }^{5}$ https://en.wikipedia.org/wiki/Mikhail_Bakhtin 
contest" (Mouffe, 2000, p. 22) violence and antagonism by accepting the unavoidability and desirability of power, authority, and politics. Violence, hegemony, repression, and antagonism should be curbed by dialogic reflection (i.e., critical dialogue): "[Political decisions] entail an element of force and violence that can never be eliminated and cannot be adequately apprehended through the sole language of ethics or morality. We need a [dialogic] reflection of the political proper" (Mouffe, 2000, p. 130).

The notion of "friendly enemy" implies an appreciation of dissensus as a permanent productive force (Rancière, 2004). Mouffe argues that this appreciation is rooted in the fact that truth exists on the boundaries of unmergeable consciousnesses that are essentially (but not fully) opaque to each other ${ }^{6}-$ nobody can claim a monopoly on truth:

... for democracy to exist, no social agent should be able to claim any mastery of the foundation of society. This signifies that the relation between social agents becomes more democratic only as far as they accept the particularity and the limitation of their claims; that is, only in so far as they recognize their mutual relation as one from which power is ineradicable. The democratic society cannot be conceived any more as a society that would have realized the dream of a perfect harmony in social relations. Its democratic character can only be given by the fact that no limited social actor can attribute to herself or himself the representation of the totality. The main question of democratic politics becomes then not how to eliminate power, but how to constitute forms of power which are compatible with democratic values (Mouffe, 2000, pp. 21-22).

The goal of this agonistic dialogue is not to convince the other side of your own truth, but to invite the friendly enemy to help yourself test the limits of your own truth in your own paradigm to create what Bakhtin called "internally persuasive discourse" (Bakhtin, 1984; Matusov \& von Duyke, 2010). The counterarguments introduced by a friendly enemy from an oppositional paradigm may help a student deepen or transform their own perspective through responding to these counterarguments and challenges, reinterpreted within the student's original paradigm. This reply to the hostile paradigmatic reinterpreted challenges does not need to be persuasive for the friendly enemy. Rather, the targeted audience for the student is the community of the student's own paradigm, bystanders, important powerful outsiders, and newcomers who can be recruited by the new intellectual twist. The goal of agonistic dialogue is the student's personal self-growth within the original paradigm that involves deepening one's own paradigm, finding its limits, and, thus, bringing power to it (i.e., winning over important others-mostly third parties and occasionally even opponents-and strengthening existing alliances). The benefits of agonistic dialogue are pragmatically and ethically mutual for both oppositional paradigms, which are rooted in their self-growth due to these mutual challenges and responses to them and in tolerance and even in appreciation of each other (i.e., the ethic of engagement with an agonistic irritating other). There is no expectation for a consensus. When agreements eventually occur, they remain "conflictual agreements" (cf. Mouffe's "conflictual consensus"). Although an action of a friendly enemy can be destroyed (e.g., by a democratic vote), neither their idea nor the friendly enemy itself is destroyed in the agonistic relationship.

The paradigmatic positions of friendly enemies engaged in an agonistic dialogue - "the internal territories" of the paradigms - cannot be understood as self-sufficient positions. Their paradigmatic and ideological meanings and truths emerge and can be understood only in dialogic relationships to each other's charges and counter-charges. To understand a position of one is to reconstruct historically unfolding agonistic dialogue among them (Matusov, 2007). The oppositional paradigms help to reveal the boundaries of each other's truths that are invisible from within.

${ }^{6} \mathrm{Cf}$. "... [a] person in his/her essence is untranslatable in principle. But there is a hope for [partial] translatability. And this is what is the hope for the encounter/meeting" (Lobok, 2014). 


\section{An encounter of strangers for authorial self-growth}

This type of dialogic encounter has been developed by a Russian philosopher of dialogism Mikhail Bakhtin and a Russian dialogic educationalist Alexander Lobok. Unlike political or paradigmatic friendly enemies, who fight for domination over resources and people, friendly strangers are not involved in a relationship of competition and dominance - the relationship with a friendly stranger is not agonistic or antagonistic in its nature (although competition and domination can be dynamically intertwined into the complexity of the friendly stranger relations, of course). In a dialogue with a friendly stranger, the other provides inspiration, nutrition, support, provocation, joy, and growth for one's own subjectivity, which is not necessarily expected in the agonistic relationship with a friendly enemy,

The encounter/meeting is the ultimate opportunity to hear [myself] in the other. This other can be a physical interlocutor or it can be an encounter with a text or with some phenomenon of culture, which forces me to make that very effort. The encounter/meeting, which I am talking about, is what presupposes my great effort to encounter the other who is not overlapping with me (i.e., opaque to me), but who is interesting for me. [This meeting generates] a point of puzzlement/surprise and at the same time it is a point of some kind of unusual joy of discovery of myself in the [other] unexpected for me. This is as if [the other] talks about something that is deeply intuitively clear to me. And at the same time, [the other] creates the space, in which these deep intuitions of mine begin to live and begin the fireworks of my own creative thinking ... [The other] capture[s]/hook[s] something in me, which is essential about me. To "capture/ hook" something in me, means to provoke, spark, self-actualize, and initiate some kind of my own activity. And this situation of the encounter/meeting that I am describing here is, as a matter of fact, an educational situation. Genuine education unavoidably involves an element of provocation.

What is important ... is that my encounter with the [others] is the space of my own personal self-growth, my own self-actualization. The encounter with [others] is the process of my own self-making/self-creation/selfbecoming and, thus, my own self-education (Lobok, 2014; the fragments are from two video conferences, cited in Matusov \& Marjanovic-Shane, 2015, p. 216).

Lobok's dialogic position can be characterized as a critical dialogue of friendly strangers aiming at self-growth. People are viewed as authors of their own ontological growth. Others are regarded as provocations for the author's personal self-growth. An author can also provide a "review" (i.e., dialogic finalization) of another author as a provocation for his/her authorial personal self-growth. The focus here is not so much on "getting it fully" and/or "getting it right" - i.e., getting the exact subjective position of the other, which is both impossible and undesirable—but on being dialogically provoked for self-actualization. Interaddressivity - interest in another — is about dialogic provocations for the authorial self-growth.

Lobok's framework is deeply authorial and ontological. It focuses on authorial transcendence of the given - in a genuine encounter with the other, "the person transcends (getting bigger) him or herself" (Lobok, 2014). It is about life experience and life itself and not about the (re)production of knowledge. It is about authorial culture-making:

For me, the biggest issue is what dialogic pedagogy is for. If dialogic pedagogy is for production of new knowledge in students-I'm not interested in such dialogic pedagogy. If it is for something that I, as a teacher, don't know yet, then I am interested in this dialogic pedagogy. I don't want to get stuck in the horizon of the new knowledge that I have to acquire ... Life is not a means for something, let's say, for getting new knowledge. Life, for me, has its own self-sufficient and intrinsic value. The highest truth of life is not rooted in some kind of results, at which I arrived or which I acquire, but in that I get goose bumps on my skin because I feel that I have been living a wonderfully authentic life. I am taken by a feeling of the authenticity of the experience of my life in the moment, and this is the highest truth of life. And, it doesn't matter whether I get new knowledge or not, whether I

Dialogic Pedagogy: An International Online Journal | http://dpj.pitt.edu DOI: 10.5195/dpj.2022.497 | Vol. 10 (2022) 
write a new book or not, [rather it is] this result of living an authentic life. I know that, if in my life the situations of authenticity have occurred, the state of final feelings and final experiences (perezhivanie, in Russian) - that means that life has been realized. If I live an authentic life, I am happy (Lobok, 2014; cited in Matusov \& Marjanovic-Shane, 2015, p. 217).

This type of dialogic encounter provides respect for the students' authorial agency based on them treating each other as dialogic provocations for each other's authorial self-growth-i.e., critical selftranscendence. Education is viewed as a self-forming unique universe.

\section{A "hanging-out" encounter of friends}

In contrast to Mouffe's agonistic dialogue among political and paradigmatic friendly enemies and Lobok's dialogue among friendly strangers for authorial self-growth, Matusov and Marjanovic-Shane view another possibility for a good dialogue in education - a "hanging-out" critical dialogue among friends (Nikulin, 2010). Friendship is a relationship that is not defined by any specific event or discourse, or topic, or goal; rather, it is the enjoyment of being together across many diverse events, discourse, topics, genres, and goals - it opens up spaces for many overlapping possibilities (i.e., heterodiscoursia, see Matusov, 2011). Friends' interest in each other is self-contained and intrinsic - it is not reducible to anything nor does it need any particular reason, including their authorial self-growth and agonistic dialogue. The basis of friendship is mutuality without reciprocity. Friendship is not so much based on the exchange of favors to each other - doing something to please the other, expecting in return that they do something they otherwise may not want to do - but on intrinsic pleasure from being together and engaging with each other (Matusov, Smith, Soslau, Marjanovic-Shane, \& von Duyke, 2016). Agonistic and self-growth dialogues are task-oriented and self-oriented (i.e., one's own paradigm or self-growth) whereas hanging-out dialogue creates a joint living space and is relationship-oriented. In this sense, friends have meta-interaddressivityoverall interest in their own involvement with each other across vastly diverse life contexts.

Critical dialogue among friends is about being together through a deep interest in, and enjoyment of each other's subjectivity and taking care of each other. The subjectivity of the friend is accessible but never fully known in the tension between a genuine question and a serious answer. It is metainteraddressivity driven by the relationship and interest in the other and not primarily by authorial selfgrowth. Thus, the opaqueness of consciousness is preserved in friendship relationships because it is defined by a deep, unconditional, and sustained interest of friends in each other across contexts and discourses, rather than the like-mindedness and mind-reading as Vygotsky (1986) and some other scholars assume (see Matusov, 2011, for more discussion).

Friends sacrifice for each other rather than for an idea or a cause. In contrast to Aristotle who claimed, "Amicus Plato, sed magis amica veritas" ("Plato is my friend, but the truth is a better friend"), in friendship, we can say, "Amica veritas, sed magis amicus Plato" ("Truth is my friend, but Plato is a better friend"). A friend is the final cause of friendship.

\section{Other types of the encounter at the University of Students}

As the enterprise of the University of Students unfolds, we expect to observe and capture other forms of dialogic and non-dialogic encounters among the students (and between the students and the teachers/advisors). Non-dialogic encounters may involve instrumental encounters when a student may not be interested in a unique consciousness of another participant (e.g., a fellow student, teacher, advisor) or even their own consciousness, but rather in a particular knowledge or a desired skill. 


\section{Agora: The Classical and The Digital}

The Classical Athenian Agora, located in the olive gardens at the foot of the Acropolis, was the center of the public life of the Athenian polis. It was, first of all, a marketplace where locals and strangers brought their merchandise for sale. It was also the judicial place. Male Athenians came to check if they were chosen to serve on a jury for some trial case in the Peristyle Court. It was the political center of the polis of Athens' government - the Boule (legislative and executive parliament) and the Prytaneis (a standing committee for immediate ruling) - and political assemblies to discuss public issues, hear arguments, and make decisions. It was a place of worship with several temples. It was the place to ostracize your fellow citizens by dropping a tag with the name of an offender in a special jar. It was the place of public gossiping and public festivity. It was a place to meet lovers (mostly male). And, yes, it was a place to eavesdrop, listen to, address, and discuss interesting political and philosophical issues with wise men of the day. This was the place where people came to hear Socrates, his disciples, sophists, and other philosophers, to freely come and go away from him as they wished. It was the place for serendipity: come to buy goods, stay to hear Socrates or the Stoics ${ }^{7}$.

Agora was the place for encounters and mixing the unmixable. It was the place for an encounter of strangers, enemies, opponents, lovers, and friends. It was the place for preplanned activities and serendipity, the place for on-task monologues and heterodiscoursia, the place for poiesis and praxis. Agora was the place for the sublime and mundane. Agora was the place for work, duty, and leisure. It was the place that had a strict regimen and frivolous, non-binding participation, eavesdropping, and observation. It was the place of nature and the artifact. It was the place of mixing the public design and the private intent, regulation and improvisation, strict ritual, and unbridled festivity. Agora was ruled by Apollo, the god of the sun, of rational thinking and order, appealing to logic, prudence and purity. And also, Agora was ruled by Dionysus, the god of wine and dance, of irrationality and chaos, appealing to emotions and instincts ${ }^{8}$. That is why we think Agora is the perfect metaphor for the University of Students.

We envision the Digital Agora as a social media meta-platform serving diverse functions for diverse people with diverse goals, desires, and aspirations. There should be a possibility for one point of entry for a person (with one account) that allows the person to access and organize diverse platforms for shopping, art, political participation, gossiping, news, clubs, VR-, video-, audio-, text- chatting in real-time, worship, dating, entertaining, secluded meeting places for friends and families, games, one-time events - like presentations, and so on. There should be possibilities for the focused organized activities and for the serendipity for a person to bump into something unexpected and interesting. There should be possibilities for central and peripheral participation. There should be possibilities for public, semi-public, semi-private, and private activities and events. There should be notifications for the chosen activities, announcements,

feel overwhelmed and distracted by all these notifications. Of course, the person should have many choices of how to configure these notifications. We think that the creation of such a user-friendly Digital Agora is probably the biggest challenge for our University of Students.

\section{The alternatives to the University of Students}

\section{The University of Masters}

The University of Masters is a Professor-led authorial education. This can take many forms, but it amounts to the same thing: teacher-defined education. Master (in a medieval sense - e.g., professor-

\footnotetext{
${ }^{7}$ To visualize the Classical Agora in Athens, visit: https://youtu.be/UasvHBfyRGI. Also, Roman Forum was another marketplace similar to the Classical Agora.

${ }^{8}$ Cf., Alexander Sidorkin's "three-drink theory" of educational dialogue (Sidorkin, 1999).
} 
expert) defines the nature of education for their students (apprentices): what is education, what to study, how to study, with whom, where, when, how to assess their students, when to stop to study, when to expel a student, when and how to reward and punish a student, and so on. Master is an acclaimed virtuosopractitioner and an authorial educator. Here are examples of such Masters: Leonardo Da Vinci, Michelangelo di Lodovico Buonarroti Simoni, Lev Vygotsky, Jean Piaget, Maria Montessori, Dmitry Bykov, Mikhail Bakhtin, Vladimir Bibler, Cornel West, Barbara Rogoff, Jean Lave, Richard Feynman, Aristotle, Alexander Lobok, Paulo Friere, Dmitry Vrubel, and so on ${ }^{9}$. Students (apprentices) usually voluntarily, but unconditionally, submit themselves to their Master and the Master's demands. The Master rules: "My way or the highway!" "If you don't like my teaching - leave!" Students can make suggestions, but it is up to the Master to accept or reject them. Sometimes Masters may organize themselves in loose teaching guilds for coordination, sharing resources, gatekeeping, and mutual support, which, however, usually do not limit their pedagogical and practical authorship and creativity.

There are several major related differences between the University of Masters and the University of Students. The University of Masters is based on the Kantian principle of educational paternalism and foisted education; while the University of Students is based on students' self-education and voluntary participation in education on the students' terms. In the University of Masters, education is fully defined by the masters - i.e., by the teachers: what is the purpose of education, what is its curriculum, how to guide, when, where, with whom, and so on. In contrast, in the University of Students, education is defined by the students, with or without the involvement of other people. The student remains the final authority for their own education. The University of Masters totalizes the odigósdidact form of education - i.e., teaching - as the main and only form of education. Meanwhile, in the University of Students, the odigósdidact is one of many forms of (self-)education. Finally, the odigósdidact itself is different in these two universities. In the University of Masters, the odigósdidact is unconditionally defined by the Master. In contrast, in the University of Students, the odigósdidact is always conditional, based on the student's consent, which student can legitimately withdraw at any time.

At the same time, both the University of Masters and the University of Students define education as authorial. In the University of Masters, it is the Master who is the sole and main author of the student's education. The Master authors the goal of education, its curriculum, its instruction, and its organization. In the University of Students, it is the Student who is the primary and final author of their own self-education. However, in the University of Students, a student can conditionally accept their Master's authorial guidance, organization, and even imposition of the education. At this point, the University of Masters and the University of Students differ from the University of Credits.

\section{The University of Credits}

The University of Credits has mainly emerged from the University of Masters at the dawn of the nineteenth century and by now it has almost a complete monopoly on (higher) education. The University of Credits is based on the standardization of education, where education - its goal and quality - is defined in advance by some bureaucratic and/or expert authorities via preset criteria and benchmarks. The educational preset criteria and benchmarks can be defined by a set of particular courses needed to be successfully taken by a student, a number of "credit hours," by passing exams and tests (standardized or not), by getting good grades, by achieving high enough "Grade Point Average," approval by the instructor, and so on. When these preset criteria and benchmarks are met the "taken" education is credited to the student. Two equally credited students are considered to be "the same" by the credentialed educational system in terms of their "learning outcomes" and their educational status.

\footnotetext{
${ }^{9}$ See an incomplete list of modern Universities of Masters here: https://universityofstudents.org/kin
} 
There are several birthmarks of the University of Credits as the logical consequence of the standardization of education. The first is educational paternalism and foisted education that we discussed above. This feature of the University of Credits is akin to the University of Masters.

The second is institutionalism of education - a belief that any educational problem can be solved by an educational institution, specifically its institutional organization and policy. Educational institutionalism views education as a system, an educational system (rather than an authorial practice by a student or a teacher/professor).

The third is educational standardizationalism - a belief that the quality of education and its distribution (i.e., fairness, justice) can be achieved only or mainly through standardization of all aspects of education: its curriculum, instruction, organization, assessment, teacher qualification, classroom management, and so on. It views teachers as mutually replaceable, and it defines education as making students mutually replaceable. Recently, this ideology of standardizationalism has become increasingly rationalized by so-called "research-based practice" or "best practice" borrowing these terms from the medical practice (Hargreaves, 1996, 1997). Critics of standardizationalism argue that educational practice is essentially praxis and not poiesis, i.e., a preplanned practice amenable to standardization (Carr, 2006; Hammersley, 1997; Matusov \& Brobst, 2013). Aristotle (2000) defined praxis as an activity, which goal and quality emerge in the activity itself. Conversely, in poiesis, the definition of the activity's goal and quality pre-exists (i.e., is preset) the activity itself.

The fourth is summative assessment - it is a practice of sorting people for the purpose of determining their access to some social goodies, such as employment, contracts, desired education, occupation, election (in the past), etc., based on their competence with some predefined practice and criteria (e.g., passing an entrance exam). Summative assessment has had a long history and legitimacy outside of educational institutions, but with the rise of credential education, summative assessment penetrated the educational practices itself. Critics of educational summative assessment raise a question (among many others) of what the person's history of institutionalized education has to do with the person's current competence (Matusov, Marjanovic-Shane, \& Meacham, 2016).

Finally, the fifth feature of the University of Credits is credentialism itself - a belief that the quality of education and students' competence can be fully or somewhat accurately measured and defined by educational credits (e.g., grades, test scores, portfolios, diplomas, degrees, credit hours, a list of taken/passed courses). Educational credit signals competence (Caplan, 2018; Labaree, 2010).

Critics of educational credentialism argue that ubiquitous and omnipotent credits distort education by distracting students from the focus on their educational process to obtaining credits (Labaree, 2010). Even more, educational credit becomes more important than actual education in the eyes of students and even some employers:

Imagine this stark dilemma: you can have either a Princeton education without a diploma, or a Princeton diploma without an education. Which gets you further on the job market? For a human capital purist, the answer is obvious: four years of training are vastly preferable to a page of paper. But try saying that with a straight face. Sensible versions of the signaling model don't imply the diploma is clearly preferable; after all, Princeton teaches some useful skills. But you need signaling to explain why choosing between an education and a diploma is a head-scratcher rather than a no-brainer. ...

The main objection to the "guerilla education" argument, though, is simply, "Almost no one takes advantage of it." That's precisely my point: the fact that almost no one grabs a free elite education shows human capital purism is false. For the signaling model, in contrast, the freebie is a mere illusion. Universities don't card 
because they don't need to. Unofficial education is vanishingly rare because it sends employers an invisible signal—also known as no signal at all (Caplan, 2018).

The educational credentialism, on which the University of Credits is based, should not be confused with the practice credentialism. In the practice credentialism, the practice safeguards establish the criteria of the minimum requirements for safe and competent practice and certify a person based on these criteria. A good example of the practice credentialism is a driving license. A prospective driver must prove to the driving authority that they can drive safely enough and know traffic rules sufficiently. In contrast to educational credentialism, the person's educational history - where, what, and how the person studies to achieve their competence - is unimportant for the practice credentialism.

The University of Students can accommodate both the educational credentialism and the practice credentialism, if and when a particular student commits to any of them. The educational credentialism can be a part of the student's autopaternalism as a particular form of self-education, when the student does not fully trust themselves to pursue desired education, described above. In this case, the student voluntarily and conditionally copes and submits themselves to the forms and organization of education from the University of Credits. As to practice credentialism, a student can define their own goal of education as the preparation for acquiring the practice credentials (e.g., driving license, passing a job interview, getting skills and knowledge required by a derided job). Of course, at the University of Students, students are free to choose their own educational goals and change them or quit their education at will at any point.

\section{The history of the University of Students}

\section{In Ancient Athens}

In Ancient Athens, the University of Students was probably represented the best by Socrates's gatherings and Plato's Academy - at least, based on the description of their practices that survived (Dancy, 1991; Plato, 1997; Xenophon, 1994). Theodora Penny Martin reported about "women's study clubs back to Periclean Athens and the home of Aspasia, where, it is said, women met weekly for 'intellectual improvement"' (Martin, 1987, p. 4). People, mostly rich free citizens of Athens (although there were some foreigners), mostly men (although there were a few women attending Plato's Academy ${ }^{10}$ ), came to Socrates and Plato to discuss their inquiries (e.g., Meno: what is the origin of virtues), or ask for advice (e.g., Aristarchus: how to take care of his numerous relatives who took refuge from a war in his household), or just listen to their conversations with other people. At times, Socrates and Plato initiated discussions of the inquiries of their own or even gave a speech (e.g., Plato's monologue "On the good"). The attendance was free of charge. Some people sought these meetings and came intentionally. Some bumped into them. Some joined via serendipity. Anyone could join or leave at any time, jump into a conversation, interrupt with a new comment, topic, or question, eavesdrop on the conversation, or attend and observe silently while being a part of the group. Despite clear admiration (or aversion by some participants, e.g., Anytos who was Meno's friend) to Socrates or Plato, the role between the teacher and the student was flexible and situational. Participants were viewed by each other as "consciousnesses with equal rights" to be taken seriously (Bakhtin, 1999, p. 6) with their own legitimate final judgment for the truth. The overall nature of this education was a form of leisure (literally, "school" in Greek) in pursuit of a good life and self-growth (self-actualization). The Ancient Athenian Universities of Students declined with the decline of the Athenian democratic state.

${ }^{10}$ http://www.hackettpublishing.com/philosophy/women-in-the-academy 


\section{In the Middle Ages}

Historians of the Medieval universities report that the first University of Students (aka "studentcontrolled university") emerged in Bologna, Italy, at the beginning of the thirteen century as a result of complex political and economic struggles among foreign students, citizens of Bologna, masters (professors, mostly citizens of Bologna), the Church, the State, and the Holy Roman Emperor (Cardozier, 1968; Cobban, 1980). To protect themselves from Bologna citizens' abuse, violence, and exploitation, foreign students organized themselves into "nations" (later "colleges") based on the country of their origin. The students' "nations" were organized into a congregation with the elected legislative council representing all "nations." The council elected the rector of the university with executive power. The rector had to be a student of at least 24-years, having at least five years' study of law, unmarried and designated as a secular clerk by the church. The student-based university council, rector, and the students' power as such were legally recognized by the State, the Church, and the Bologna Magistrate. Bologna students were coming from wellto-do aristocratic families with powerful political connections, relatively old (18-30 years old), with rich past experiences, organizational and even military skills, and money. They brought money and prestige to the city, state, and church and provided theological, legal, medical expertise both while at the university and later. The students collectively hired their masters (professors), rented houses, and bought food, services, and goods from locals. They could threaten to leave the city and they did leave when their collective or personal demands were not met. They made collective bargaining agreements and collectively boycotted businesses that they did not like. Finally, they presented an exigent organized military force when needed.

The student-elected congregation of the university established rules and regulations that applied not only to themselves but also to professors and, indeed, to the servants, landlords, and others who did business with the students. The professors (masters) must take an oath of obedience to the student rector. They did not have voting rights. All issues of academics were decided by the students: the curriculum, the instruction, the organization of the course, and so on. The professors entered with their prospective students into a contract which dictated to the professors what subject they would teach, which books they were allowed to use, how many students they should have and keep (usually no less than five), in which order they should read and discuss the books, when they would start and finish, where they would teach (it could be at the professor's home), how much the students would pay to the professors, and so on. The contracts specified many regulations for the professors. Not only the professor's teaching was regimented but also, at times, their private life if it might affect their teaching. For example, the length of the honeymoon was limited to one day for the professors to minimize the disruption of the teaching by their wedding. When these regulations were violated by the professor (e.g., by missing a class or by having less than 5 students attending a given lecture), he would be fined or even dismissed from the job without pay or with only partial pay. In anticipation of the fines, before starting their teaching, the professors must deposit some money in a bank to pay fines. However, when a professor was popular among his students, the teaching job was very lucrative, competing well with income from their professional trades. Medieval Universities of Students defined education mostly as a pursuit of vocation -- e.g., in theology, medicine, arts, law: "As vehicles for community needs, the medieval universities were largely vocational schools training students in the mastery of areas of knowledge and analytical skills which could be utilised in the service of the State or Church, in teaching or in the secular professions of law and medicine" (Cobban, 1980).

Historians argue that the first student-controlled university, the University of Bologna "evolved naturally from the circumstances under which the university developed" (Cardozier, 1968, p. 944) without any ideological, philosophical, pedagogical, economic, or political design guiding this process. However, following student-controlled universities used the University of Bologna as its model: 
The student-university [at the University of Bologna] emerged as an attempt to solve empirical problems: it was not advanced as a visionary thesis of European university organisation. But at Padua student power in the early fourteenth century bore the stamp of a conscious imitation which embodied the assumptions on which the Bolognese system was based. The Paduan model expressed the belief that the form of university which had evolved at Bologna should serve as a prototype for university organisation in southern Europe. The planned adoption of the Bolognese structure helped to promote the idea that the core and essence of a university was the student guild (Cobban, 1980).

The student-controlled universities (i.e., the University of Students) spread throughout Europe alongside with the University of Masters and their hybrids. The example of the latter is the University of Prague, where, in being an overall University of Masters, law students "insisted on privileges comparable to those at Bologna and were permitted to withdraw and form a university of their own" (Cardozier, 1968, p. 945). Historians have noticed that whether a Medieval European university was a University of Students, or a University of Masters, or a hybrid of two depended on the following conditions: foreign vs. local students, professors paid by students' fees vs. by salary issued by the city (or the State), older (18-30 yearolds) vs. younger (13-16 year-olds) students, social class and wealth of the students (aristocrats vs. burghers), student major in law vs. arts, the strength of masters' guild, local politics, and so on. Universities of Students were more spread in the South of Europe while Universities of Masters in the North.

The University of Bologna finally lost its student-controlled status in 1796 when Bologna became occupied by Napoleon's troops and the university was closed. When it was reopened two years later, in 1798, the rector was no longer a student elected by the student congregation but an appointed professor. The end of the University of Students model was both economic and ideological. "The establishment of the salaried lectureship as the normal method of academic payment sounded the death knell of student power" (Cobban, 1980). University education, defined as vocational in its nature and overwhelmingly orientated towards the professional needs of society, became increasingly reflective of the establishments which they served. In addition (or even because), the Medieval European student-controlled universities were increasingly criticized for their corruption, nepotism, manipulation, academic inefficiencies, abuse of power, exploitation of professors, and so on. However, historians of Medieval universities observed similar, if not worse, shortcomings in the Medieval Universities of Masters: "The extent of academic irresponsibility and corruption and how it was apportioned between the students and their lecturers [i.e., masters] in the Middle Ages cannot be assessed by any quantitative means" (Cobban, 1980).

\section{Organizing self-education in recent history}

In the early $19^{\text {th }}$ century in the United States, there was a growing proliferation of informal self- and mutual- education events, circles, study-clubs, and educational societies, involving discussions of issues of mutual interest and urgency, books, and lectures. "A circle of friends meeting at home would engage a lecturer of an evening paid for by ticket sales to friends" (Martin, 1987, p. 7). These events, circles, studyclubs, and educational societies involved "cultured" men and women, mostly of the middle and upper classes. However, by the end of the $19^{\text {th }}$ century, this movement became increasingly gendered as many thousands, if not millions, of women formed exclusively women's "study clubs." In the United States, "by 1906, five thousand local organizations had joined the General Federation of Women's Clubs, and it has been estimated that they constituted only five to ten percent of the clubs in existence" (Martin, 1987, pp. 34). Martin argues that because women were oppressed and discriminated against and, thus, often could not participate formally and publicly in the economy and politics, they turned their energy and attention to self-education in study clubs for self-realization. Some involved of these clubs were based on voluntary attendance, but some demanded mandatory attendance, where unexcused absences were meticulously recorded in the minutes. The main purpose of this self- and mutual- education was "cultivation and 
improvement of the mind" and included both very conservative, radical, and politically indifferent women and their interests, "To the conservative woman, federation brings the gradual breadth of mind; to the radical woman it brings the knowledge of the individual point of view, the best lesson ever learned; to the lonely woman it brings friend and fellowship; to the unhappy, useful work and forgetfulness of self; to the rich woman it has brought knowledge of the obligation entailed by her possessions; to the poor, it has brought genuine help and uplift in multitudes of cases" (Winslow, 1912, p. 127). It seemed that these women's study clubs were based mostly on the symdidact form of self-education.

Another powerful form of self-education in the $19^{\text {th }}$ century was the "lyceum" movement started by Josiah Holbrook in 1826 in the United States, after its success in the United Kingdom two decades before. Lyceum was originally designed for (male) artisans and farmers interested in mechanics, practical applications of science, and newly emerging machines. Later it diversified its curriculum to include history, travel, biography, foreign affairs, the art of living, which also diversified its studentship to include women and middle-class folks. It offered a series of lectures and public forums, organized in standalone events, lecture courses, or regular study/discussion evening meetings on diverse topics of the public's interest (except religion and politics - controversial subjects). The lyceums also promoted the establishment of public libraries. The lyceum movement was financed by students' fees (rather by the gentry) and run democratically by the students' majority vote on the advice of Lord Henry Brougham, a co-founder of the lyceum movement in the UK in the early 1800s (Bode, 1968, p. 6). Holbrook defined the purpose of lyceum as self-education, "Self-education is, in all the departments and all the operations of the lyceum, its most prominent feature" (Bode, 1968, p. 68). He provided a list of 11 specific items of the lyceum's public benefits, starting with "1. The improvement of conversation" and ending with "11. State collections of minerals" (pp. 24-26). Still, the appeal of the American lyceum was highly vocational and practical, offering upward social mobility for lower classes, while it also tried to address the public's curiosity in diverse cultural spheres. After 4 years of the first American lyceum, 16 states and 3 thousand towns and villages had lyceums (Martin, 1987, p. 33). The highly institutionalized culture of the American lyceum involving appointed curators who were hunting for popular lecturers suggests that it was probably a hybrid of the University of Students, based on the odigósdidact and symdidact forms of self-education, and the University of Masters, where Masters, the lectures and curators, dictated the students what they must study, - more investigation is needed about the nature of this type of education. The later, after 1848, the American lyceums relied exclusively on lectures and, perhaps, increasingly become the University of Masters. However, the American lyceums provided the impetus for the establishment of public libraries, which promote both solo reading autodidact and reading circles symdidact. According to Bode (1968), the Civil War put an end to the American Lyceum movement probably because vocational education became highly credentialed and institutionalized on demand of the employers. After the Civil War, the American Lyceums were replaced with the Chautauqua educational societies mostly aiming at the participants' self-refining by studying the high culture (Kett, 1994).

However, by the end of the nineteenth century, the Chautauqua educational societies also disappeared. The rapid industrialization put forward the University of Credits (credentialism), utilitarianism focused on employment and foisted education (Kett, 1994). Thus, the twentieth century became a decisive turn from self-education to credentialed foisted education, "No longer dedicated to imparting a way of life, social educators of the twentieth century would try to tailor specific types of knowledge to the educational interests of those diverse subpopulations. They necessarily would come to rely on bureaucracy, for now, they would have to identify prospective students, discover their 'reading interests' and 'educational needs,' and guide them to appropriate courses" (Kett, 1994, p. 222). Even adult "education for yourself" became institutionalized in the $20^{\text {th }}$ century and presented as a student's choice of classes and courses in the form of extended, uncredentialed higher education (i.e., without granting a certificate, degree, license, or diploma), with the curriculum and learning activities preplanned for the students. Adult learners of the $20^{\text {th }}$ 
century could freely choose a course for themselves in their extended adult education (e.g., the university extension) but not its curriculum, organization, learning activity, or instruction. Beyond a student's selection of the uncredentialed predesigned courses, self-education remained private, marginalized, and underground in the $20^{\text {th }}$ century.

At the end of the $20^{\text {th }}$ century and the beginning of the $21^{\text {st }}$ century, Christopher Phillips and his colleagues organized "Socrates café" for discussions of philosophical issues emerging in common people (Phillips, 2002) and "The Constitution café" for discussions of political issues and political philosophy (Phillips, 2011). He tried to spread this movement to different countries (http://socratescafe.com/?page id=74). However, observing YouTube records of the meetings (e.g., "Is Doping Cheating?", 2013, https://youtu.be/itsG486P7uc; "Free will? A Socrates Cafe at Harwood Union High School in Vermont with Christopher Phillips", 2015, https://youtu.be/99xBLa qCJw), it is not clear how much these educational practices involve genuine self-education.

There was a peripheral but important exception - the emergence of democratic K-12 schools in the late 1960s in the US (Greenberg, 1991), Norway (Jørgensen, 1971; Marjanovic-Shane, 2022, in press-a, 2022, in press-b), Sweden (Marjanovic-Shane, Kullenberg, \& Gradovski, 2022, in press) and probably elsewhere as the offshoots of the UK democratic school "Summerhill" (Neill, 1960), launched in 1921. Although, perhaps, counting less than 100 around the world by the end of the $20^{\text {th }}$ century, K-12 democratic schools (and some types of homeschooling, see Llewellyn, 1998) were a proof of the concept for schools that support full-scale students' self-education.

The situation for the opportunities and expansion of self-education drastically changed at the threshold of the $21^{\text {st }}$ century with the development and proliferation of Internet and especially its search engine designed by Google. Dissemination of knowledge, skills, opinions, values, news, fictions, intentional and unintentional falsehood, debates, forums, art, science, dialogues, fights, propaganda, Al manipulation, entertainment, shopping, dating, sex, religion, semiotic violence, philosophy, advertisement, games, communication, etc. has skyrocketed on the Internet. Social media, blogging, and webpage-making allow almost everyone to create the Internet content and, thus, to publicly participate in the creation of culture. Knowledge and access to knowledge became very cheap, while the spread of smartphones literally makes knowledge available at any time at users' fingertips. The guidance also moves online, available any time on-demand, serendipity, and on purpose defined by the learners: the Khan academy, WikiHow, the YouTube "How to do," "How to make" video channels, help forums, TED shows, podcasts, Wikipedia, video and movie streaming, and so forth. Educational philosopher Alexander Sidorkin argues that "The difference between the educated and the uneducated persons is now in their knowledge about what kinds of knowledge exist, where to find it, and how to understand and use it" (Sidorkin, 2009, p. 185). The Internet shifts the educational focus from a student's acquisition of knowledge under the watchful guiding eye of a teacher to the student's development of their own interests in desired knowledge, Internet searching skills, assessment of the quality of the found knowledge on the Internet, and dialogic understanding and authorial transformation of the knowledge. The latter - the dialogic understanding of broadly defined knowledge (i.e., dialogic social assemblies) and the authorial transformation of it - also becomes possible via the Internet: participation in forums, video and audio conferencing, and creation of new media-rich content. Education shifts from knowledge-centered to authorship-centered. The Internet creates a possibility for a transformation from the institutionalized credential-based foisted mass education of the $20^{\text {th }}$ century to the informal authorship-based voluntary mass self-education of the $21^{\text {st }}$ century.

\section{Smuggling a University of Students into a conventional University of Credits}

Some university professors have been trying to smuggle a University of Students into a conventional University of Credits when they become disenchanted with the zombified nature of foisted 
education and recognize that genuine education is self-education. Some even entertain the idea that the student is the final authority for their own education. They may feel that their conventional or even progressive teaching is a betrayal of their educational professionalism. This disturbing feeling pushes them to introduce and smuggle a University of Students into their conventional University of Credits, alas, in some compromised form.

We are familiar with exciting efforts to smuggle a University of Students - the students' selfeducation - into a conventional University of Credits that are mostly done in the United States, probably due to its decentralized and collegial nature of higher education. Professor of history Martin Duberman, the 1960s-1990s (Duberman, 1969, 2002, 2009; Hampel, 2021; Matusov, 2022, in press), professor of English Ira Shor, the 1980s, (Shor, 1996; Shor, Matusov, Marjanovic-Shane, \& Cresswell, 2017), "Open Syllabus"11 professors of education Scott Richardson (Matusov, 2015), Eugene Matusov (2021c), Ana Marjanovic Shane (2016), Leslie Gates (2020), Angela Kost, Olga Shugurova (2019), from the 2010s until now, are some of the most known examples for us ${ }^{12}$. A smuggled University of Students involves invitation and legitimatization of students' diverse decision-making: what they want to study in each class, whether or not they want to come to the class (free attendance), whether they have grades or not (and if so, how they are graded), what learning activities they want to commit (if at all), what type of pedagogical regime they want for themselves (e.g., "Open Syllabus," "Opening Syllabus," "Credential Student," "Prisoner of Education," see their description in Matusov, 2020a), democratic decision making about the organization of the class, a choice to drop from the class with a grade of their choice (aka "Prisoner of Education"), and so on.

These attempts should not be confused with Progressive Education (Matusov, 2021a), which involves professors giving students curricular, organizational, and instructional choices, open-ended assignments, portfolios instead of grades, and so on. The core of Progressivism is to hijack the student's authorial agency to make them work enthusiastically and with initiatives on the assignments that the progressive professor wants them to work on, "... let [your pupil] always think he is master while you are really master. .... No doubt he ought only to do what he wants, but he ought to want to do nothing but what you want him to do. He should never take a step you have not foreseen, nor utter a word you could not foretell (Rousseau, 1979, p. 120, the italics ours). In contrast, a smuggled University of Students involves the professor's recognition and appreciation of their students' educational goals and desires, which can be different from and even disagreeable with the professor's one, but still legitimate. To affirm the spirit of the University of Students, the students' educational goals and desires have to be above the professor's ones. This is usually a tough lesson for many professors who have gotten on a path of a smuggled University of Students (Matusov, 2022, in press). Colonization by Progressive Education often leads these professors to blame their students for passivity and conformity when they do not meet the professors' expectations in educational activism (see such complaints in Duberman, 1969; Holt, 1972; Matusov \& Brobst, 2013).

Besides the professors and students both being colonized by the conventional and progressive foisted education values, there are many other challenges for the professors and students in a smuggled University of Students. At the University of Credits, students often attend a course not because they desire to learn something important for them, but because the course is required or because it is a lesser evil for meeting some university requirements (e.g., full-time student). This institutionalism undermines a student's focus on self-education. Also, the organization of education in scheduled termed courses does not always

\footnotetext{
11 The Open Syllabus pedagogical regime makes students the solo designers of their education in the class: the curriculum, the instruction, the organization, the assessment, and so on.

${ }^{12}$ We can add efforts to incorporate students' self-education at the dawn of the University of California at Santa Cruz in the 1960 s and 1970s (Grant \& Riesman, 1978; Reti, Vanderscoff, \& Rabkin, 2020) and at MIT in the 1960-1980s (Elbow, 1971, 1986; Valley, 1974). Smuggling self-education in a traditional university also documented by an English professor Jane Tompkins 1960s-1990s, teaching at Yale, Temple University, Duke University, and the University of Illinois at Chicago (Tompkins, 1996); and by English professor Granville H. Jones at the Carnegie-Mellon University in the late 1960s (Jones, 1971).
} 
fit a student's self-education (cf. educational clubs, one-time events, autodidact, etc.). A student's life outside of the course organized as a smuggled University of Students is often (over)burdened with conventional assignments, deadlines, and work, distracting the student from self-education, leaving little energy and time for it, and putting the student into a survival mode. The course term of the smuggled University of Students is often too short for a student to recover from a culture shock, detoxify themselves from conventional schooling, trust to the professor's emphasis on the students' self-education, and start exploring their own educational interests and desires which might be outside of the predefined course.

For professors at the smuggled University of Students, there are pressures to stay under the institutional and collegial radar. The professors are often institutionally required to have preset curriculum, rigid and unilaterally pre-designed syllabi, exams, grades, forced attendance, surveillance of the students' compliance, a set of assignments, rigid schedules for the class meetings, forced assessment, deadlines, etc. - i.e., the core components of the University of Credits. The University of Credits is full of bureaucratic domination and forced collectivism that does not recognize the rights to the students' authorial learning and the professors' authorial teaching. Pedagogical and educational "innovations" and "experimentations" often must be approved by the professors' colleagues, institutional committees, and often the university administration. The University of Credits does not respect the students' and professors' negative freedom. These institutional and collegial pressures generate fears, distrust, underground mentality, hiding their practice (and mistakes), and oppressive rationalizations in the professors at the smuggled University of Students, who are afraid for the security of their jobs and promotions.

The success of the smuggled University of Students in promoting the students' self-education and ownership of their life is often mixed and limited. Many students still seek the permission of their benevolent professor for approval of their educational initiatives (Matusov, 2021c). When a professor smuggles a University of Students into a conventional University of Credits, the professor inherently becomes a benevolent dictator in the eyes of their students - this relationship of domination is always in the air. Students' freedom, which is based only on the goodwill of the professor, is a rather weak one and often under suspicion by the students. And rightly so! When freedom is granted by some authority, it can be taken away by the same authority. Freedom granted at the grace of the authority is always half-freedom. The act of empowerment and liberation of somebody by someone is always pregnant with domination unless it is the act of self-empowerment and self-liberation. Genuine freedom, as an unalienated right of the person, cannot be given but only assumed, affirmed, and protected. That was why some of us, namely Eugene Matusov, increasingly became interested in moving his efforts to create the University of Students outside of the University of Credits.

\section{In 2020-2021}

September 24th, 2020: Daria Belovol to Eugene Matusov ${ }^{13}$ and Artyom Fyodorov; Subject: New University (in Russian, translation to English is ours)

Hello Eugene. I would like to introduce you to Artyom Fyodorov. Artyom is the founder of the democratic school in Tver, here is their website http://sovum.rul. Artyom is very interested in and looking for formats for creating a university based on the same principles as self-directed democratic education at the school level. I thought you might have something to discuss.

${ }^{13}$ Daria Belovol and Eugene Matusov "met" electronically through Jim Reitmulder, a founder of The Circle School, a democratic school near Harrisburg, Pennsylvania, USA. 


\section{The University of Students: A place for joint self-education}

Olga Shugurova, Eugene Matusov, Ana Marjanovic-Shane

Perhaps we could record an interview with a zoom or just chat online about this topic in order to post the recording here svsmodel.ru or in a group on Facebook, where we collect a variety of information about self-directed education. Here it is https://www.facebook.com/groups/322045761927259

Please tell me if it would be interesting for you and at what time would it be convenient for you to meet online?

Daria

September 26th, 2020: Artyom Fyodorov to Eugene Matusov and Daria Belovol (in Russian)

Ready [to meet] at any time.

September 26th, 2020: Eugene Matusov to Artyom Fyodorov and Daria Belovol (in Russian)

Hello, Daria and Artyom.

I'm very interested. ... I'm running to the Zoom of my democratic extraordinary class "School around the world and time through the prism of cinema." I will write in essence later.

Yes, l'd like to have a Zoom meeting with Artyom to learn and share ideas about a democratic student-centered university. As a higher education practitioner, I have been experimenting with this concept for the last 13 years, mostly within the conventional authoritarian institution such as the University of Delaware. However, I have also been experimenting with a "free-range" democratic student-centered education outside of the institutional grid.

As a theoretician of democratic education, I recently have published the following special issue on Students' Freedom of Education in the Dialogic Pedagogy journal https://dpi.pitt.edu that you may find interesting and relevant: Special Issue: Students' Freedom of Education [see it at https://dpi.pitt.edu/ojs/dpi1/issue/view/12] What do you think?

Eugene

October 9th: Eugene Matusov to Artyom Fyodorov and Daria Belovol (in English)

Dear Artyom and Daria-

Here is the record of our Zoom-meeting with Artyom on Monday, October $5^{\text {th }}:<<U R L$ of the Zoom record $>>$

Artyom and I were discussing the next steps for the establishment of an International Democratic Student-Centered University (IDSCU, a tentative title ${ }^{14}$ ). Here are the steps:

1. Prepare the meeting agenda

2. Hold a meeting at SOVUM with democratic educators, students and alumni of the democratic school, and parents of those students

3. Hold a meeting at The Circle School (Jim Rietmudler's democratic school near Harrisburg) with democratic educators, students and alumni of the democratic school, and parents of those students

4. Publicize these meetings among the interested democratic educators and students around the world by creating an international website

5. Something else?

Here are provoking questions for the upcoming meetings with my brief replies (feel free to provide your brief answers, which may be different from mine or ask me questions):

${ }^{14}$ Later it became "The University of Students."

Dialogic Pedagogy: An International Online Journal | http://dpj.pitt.edu

DOI: 10.5195/dpj.2022.497 | Vol. 10 (2022) 


\section{The University of Students: A place for joint self-education}

Olga Shugurova, Eugene Matusov, Ana Marjanovic-Shane

1. Do we need an International Democratic Student-Centered University [(IDSCU)]? If so, why?

a. Eugene: Yes. Diverse people may need to have a place for a meeting and dialogue to pursue their education. This place is embedded in a rich learning environment with opportunities for guidance as needed. "University" provides the richness of diversity for the people's educational pursuits, interests, learning journeys, educational goals, domains, levels of depth, and so on - this diversity will provide synergy for particular educational endeavors.

2. What are the major principles of the IDSCU?

a. Eugene: A student's right to freedom of education. The student has the right to decide the nature of their education (e.g., instrumental, intrinsic), whether to pursue or not to pursue their education, what to study, how, with whom, and when; including the student's freedom to conditionally surrender to a chosen educational authority (e.g., teacher).

b. Eugene: When disagreements and conflicts emerge among the participants about their rights, these disagreements have to be solved democratically via dialogic persuasion, compromise, and/or democratic voting of all parties involved in the disagreement

c. Eugene: The IDSCU governance should be democratic (see item 2.b)

d. Eugene: The IDSCU must be open for all regardless of age, knowledge level, skills, educational goals, etc. unless restricted by a student volunteer association or the IDSCU government body

3. How may the IDSCU look like?

a. Eugene: A combination of diverse media: face-to-face, online, hybrid. Students can organize into "classes" with or without a teacher (or teachers), they may want to invite and hire, or pursue their education solely or ad hoc basis. Teachers can solicit their offers to prospective students. Educational long-term clubs and forums can emerge. The existing educational sources (e.g., Khan's Academy) can be incorporated.

4. How can the IDSCU be financed

a. Eugene: Fundraising, donations, endowments, tuition, and/or fees - stay away from the government funding as it has a tendency to interfere and corrupt the major principles

5. What are the limitations of the IDSCU

a. Eugene: It has to be decided via democratically

6. Other questions?

Our next meeting about the new university will be .. via Zoom: <<address>>

What do you think?

Eugene

PS I highly recommend you watch the following movie "Accepted." ("Нас приняли!") It is a comedy about a democratic university.

From October 5th 2020, Artyom and Eugene met every week until June 2021, when we switched to monthly meetings. Eventually, we created an email survey ${ }^{15}$ to check people's interest in the endeavor and invited people to join the Organizational Committee of the University of Students (a new title of our enterprise). Some people come and go but some get stuck with the Org Committee. For example, Olga (the first author) joined on November 30 and has attended all weekly meetings (except for one) and generated many innovative ideas for the development of UniS during these meetings. The organizational committee was formed in January 2021, and the committee members have had weekly meetings until June 2021. By now, July 2021, we have the following members of the Organizational committee:

- Artyom Fyodorov, Moscow, Russia, SOVUM democratic school

${ }^{15}$ https://delaware.ca1.qualtrics.com/jfe/form/SV OfeGjXCQPh8fNTT; 89 people replied by July 15th 2021. 
- Eugene Matusov, Philadelphia, USA, University of Delaware

- Tatyana Yastrebova, Angarsk, Russia, Psychologist-consultant and leader of psychological groups

- Ana Marjanovic-Shane, Philadelphia, USA, Independent scholar

- Victor Perminov, Israel, Student of Business \& Cognitive Science, University of Minerva School

- Olga Shugurova, Toronto, Ontario, Canada, Educator and Researcher

- Abram de Bruyn, New York city, USA, Graduate Student, New School for Social Research

- Ann Qiu, Shanghai, China, MEd \& MSc, Founder of iSkool Learning Company

- Alina Sharova, Moscow, Russia, Educational consultant, The Creative Foundation Islands

We created the University of Students website in three languages - English, Russian and Chinese: https://universityofstudents.org. We designed the IT support for the edu-clubs on the Google domain: calendar of events, email groups, Google forms, Google Docs, and their automatization on Zapier.com. We developed automatized processes for enrollment in the UniS and edu-clubs and for creating edu-clubs and educational events through the UniS website. We have a database of the people interested in the UniS and created a UniS Facebook group: https://www.facebook.com/groups/theuniversityofstudents. We conducted successful fundraising for the University of Students to provide financial support for its IT, raising about $\$ 600$.

Yet, we have faced challenges in the development of the user-friendly, fully automatized, Digital Agora, where any person can create an edu-club or an edu-event without our help (or with minimal help). So far, all 7 acting edu-clubs have been created by the UniS Organizers, however, some edu-events were initiated by rank-and-file members - still with our organizational help. The University of Students exists outside of the UniS through people's own organizing themselves in edu-clubs and edu-events. However, often they need help that the UniS is aimed at providing. For example, we encountered the following post on Facebook (written in Russian, translation is ours):

\footnotetext{
Friends, who knows in Kiev a philosophical circle [club] with a free visit (I mean, what are you happy about new participants)?

Maybe at universities or something else. So that not lectures namely circles where we prepare to read and then discuss the material at the meeting.

I want to study Kant, Hegel, Russell, Marx, Engels, and others in the circle of like-minded people, not just by myself ${ }^{16}$.
}

Our discussions at the UniS Org Committee are often intense, critical, frank, and friendly (including becoming friendly enemies - frenemies - at times). Here are two accounts about the UniS Org Committee work:

Katherine Petrova (Russian-English translator and staff of SOVUM democratic school): I think, I can name two important meetings, that helped me make my mind about participation in UniS. The meeting, that got me into the movie club, was some open meeting (I can't find the invitation to this meeting and watch the recording of it, but I guess it was about Unis itself) in the beginning of May, where in the

\footnotetext{
${ }^{16}$ August 2, 2021:

https://www.facebook.com/anastasia.kotlar/posts/4466961833323201? cft [0]=AZVXOx3FgKxJZ-LgJ1oRI9QOXY-

VihVZI6St0eUO0s3kxtCmKqDSgAaZcNxvYZDLs WxOScCc35s-

39CvDLgTTHmj2rf5EX5muXXBYHPJVu_ckU6SfRrdXFAn7qvntJZVOI\& tn _ = $\% 2 \mathrm{CO} \% 2 \mathrm{CP}-\mathrm{R}$
} 
end Olga (if I'm not mistaken) talked about how much she liked being in this community and what it did for her. Something in her speech got me and I felt strong urge to become part of this community. And also during that meeting you scrolled through pages with themes of movie club meetings and it made this club more real to me.

$<$ <ee below in the next section>>

The question, that I could ask myself and anyone who doesn't like the way traditional education works, is how democratic education work should, but l'm still not sure about the answer. As I see it, one of the biggest problems not only in teaching, but also in every profession that is doomed to work under capitalism, is lack of actual will to work in chosen field. I hear all the time that people choose their major, job and many other things in their life according to the potential of these things, or simply because they have to choose even if they don't like it, and it raise a lot of frustration in them. This frustration with wrong or hard choices can often find its way to the work itself, and in case with education we see teachers who are deaf to the pain of other people, both students and colleagues, so it only grows bigger.

To bring changes into this vicious circle people need to have trust in those, who surrounds them and see everyone as equals, and I want to hope that we (as a society in general) are getting there. I think, UniS is a great place to start these changes. It probably won't work as we are picturing it, and the changes won't be as big as we want them to, but it still worth to try.

Olga Shugurova: I received an email from Eugene about the University of Students and the invitation to participate in the survey and Facebook. I was attracted to Eugene's explanation of the University and felt very excited to become a part of it. Also, I was very interested in the possibility of speaking Russian there and of being a part of the international, democratic society of the UniS. At the very beginning, the idea about UniS reminded me the Soviet film "Guest from the Future" https://www.youtube.com/watch?v=OxWyvrT4jfg, and I thought that the UniS project is like a cosmic guest-idea from the future.

Each meeting is memorable in its own way. The most exciting discussion was about our collective writing about the UniS and how it may become like ["The letter" episode from The Three from] Prostokvashino ${ }^{17}$. The most disagreeable discussion was the dialogue with the Russian colleagues about our mission and how problematic the concept of culture was. Specifically, the emotional intensity of this dialogue was unexpectedly problematic to understand, translate, and counter argue at the same time. I remember that I forgot many emerging, innovative ideas while I was trying to translate Artem's and Alina's speech while also trying to understand them and also trying to disagree with them. In this entanglement of emotions and translations, the new ideas vanished like the Cheshire Cat in Through The Looking Glass.

\section{What does the University of Students look like?}

\section{Diverse forms of practice}

Currently, we have two major forms of the University of Students operation: 1) educational clubs (edu-clubs) and 2) one-time educational events. We have seven acting edu-clubs in English and Russian languages meeting over Zoom: https://universityofstudents.org/clubs. So far, all acting edu-clubs were organized and have been maintained by organizers of the UniS. However, we have already had occurrences when one-time educational events were organized by rank-and-file members of the UniS. We are waiting for a moment when an edu-club will be started by a student who is not an organizer of the UniS. Anyone can enroll in the UniS or subscribe to the UniS Facebook group, create or join a UniS edu-club or organize a UniS one-time event, or support the UniS via a donation

17 In this episode a 7-year old boy, called Uncle Fyodor, his cat, and his dog, write a letter to Fyodor's parents in a sequential manner, without any coordination with each other, see https://www.youtube.com/watch?v=X2x8rlf5HRU (in Russian). 
(see https://universityofstudents.org/\#action).

What does an edu-club look like?

Below are two accounts from two edu-clubs: the Movie edu-club's "objective" account of a discussion and the Educationalist club's "subjective" account.

Movie edu-club discussion

The educational club "Schooling around the World and Time" was started at the University of Delaware in early September 2020. By the end of 2020, it moved to the University of Students. Eugene Matusov decided to try "higher education in the wild," by inviting education- major and minor undergraduate and graduate students at the University of Delaware to watch and discuss movies about education documentaries and fictions of different countries and times. As a result of building the University of Students, Eugene moved the edu-club away from the University of Delaware. It was easy to do because the weekly meetings of the club were on Zoom due to the Covid-19 pandemic. In past, we watched and discussed such movies as "Captain Fantastic," "Summerhill at 70," "The hole in the wall," "Please vote for me," "Hindi Medium," "Accepted," "Detachment," "Socrates Cafe," "The Class," "Sociocracy: School Circles," "The Prime of Miss Jean Brodie," and more.

This is how one of the edu-club participants, Katherine Petrova from Russia, describes the importance of the movie club for her:

...And the other meeting that felt special to me was the first meeting of the movie club that I attended on the 14th of May. We discussed the French teacher/musician ${ }^{18}$, who seemed progressive [teacher] in comparison to other teachers in the school, but actually he was quite manipulative, and it would be wrong to call his way of teaching "democratic." During that conversation something just clicked for me, because I finally understood what felt so wrong about all the good teachers in my life - none of them was really democratic, and their goodness usually disappeared as someone didn't respond to it the way they wanted. And this understanding made it clear how I see myself in pedagogy (which is democratic, cooperative and as non-judgmental as it's humanly possible). Also, I felt grateful to find people who can confirm my thoughts about the system that is indeed wrong and that it's not me being crazy and/or lazy.

To give a reader the sense of the edu-club discussions, we provide the following fragment from one of edu-club's discussions. The "Schooling around the world and time" movie club gathered on Friday, December $4^{\text {th }}, 2020$ (our $14^{\text {th }}$ meeting since starting the club) at 10 AM EST to discuss the British movie "The Prime of Miss Jean Brodie" (1969, 1h56m, all-girl high school, progressive education, drama). Seven people were present: Diana (USA), Olessya (Canada, born in Kazakhstan), Daria (Russia), Scott (USA), Sonia (Romania), Ana (USA, born in Yugoslavia), and Eugene (USA, born in the USSR). All but Sonia watched the movie in advance.

As usual, we started the club meeting by selecting the next movie about education to watch (it became the documentaries "Educating Peter" and "Graduating Peter" about the beginning of special education inclusion in the USA). Then we watched selected fragments from the movie "The Prime of Miss Jean Brodie" of our interest and split into two groups to discuss them (Group\#1: Ana, Daria, and Sonia; Group\#2: Diana, Eugene, Olessya, and Scott). After the group discussions, we reunited and discussed the movie altogether. Below is the beginning 15-min fragment of the 42-min total discussion. At some point,

${ }^{18}$ French fictional movie "Les Choristes" "The Chorus" in English, 2004. 


\section{The University of Students: A place for joint self-education}

Olga Shugurova, Eugene Matusov, Ana Marjanovic-Shane

people started leaving the Zoom meeting and the last two people closed the Zoom room. The record was lightly edited for readability.

Ana (the facilitator of the meeting): We are interested to hear what you were talking about [in your group] then we'll tell what we're talking about [in our group]. So, what were you talking about?

Dana: Hmm, I guess we were talking about the progressive movement and, um...

Eugene: and sex [laughing]

Diana: [smiling] and sexist views of women, um, and the violence of the movie. Eugene was telling us how [pedagogical violence] was very characteristic of the early philosophers or beginners of the progressive movement in education and how the students were at the center [of progressive education]. You give [the students learning] experiences. But manipulation is not off the table for the progressive movement. And so, all of that was very negative and violent to me, um, because it's not quite, my view, of what it means to be student-centered, but, uh, but I don't know. Does anybody want to add what else we talked about?

Eugene: One thing that's important, Diana, what you brought in [our group's discussion] was this idea of "listening." I think it's very interesting that progressive education emphasizes listening to the students, but that listening, very careful listening, is directed towards [successful] manipulation [of the students] in order to ignite them, to create their interests, to bring them to the [taught] curriculum: the poetry or history or art - [you name it]. [For that,] you will need to carefully listen to [the students in order to] manipulate them [well]. So, we raised that question, "What's other [non-manipulative] type of listening? What alternative types of listening students can be?"

We also discussed [pedagogical] violence, sexual violence, and sexism. We talked about this sexism in the thirties and [sexual] violence versus in the sixties. [We wondered if the movie presented a critique] of sexism in the thirties [from] the sixties' [perspective], or was it a problem of the sixties as well? This idea that for men to be passionate, they have to be [sexually] abusive -- is very [disturbing.] And also Dana has a similar [feeling] that I have... like we watched that movie a long time ago and we didn't remember being so disturbed [by the movie]...

Ana: Me too.

Eugene: ...uh, just by this sexism and sexual violence as now. And it's interesting, the change [of our sensibilities] happened in our time. That's a very interesting...

Ana: I think also in the...

Eugene: Olessya, do you want to add anything because I think you also made some interesting?...

Olessya: Yeah. Well, for me it was the first time watching it [laughing]. I think I didn't read the description [of the movie] too carefully, or maybe, I read it and then forgot about it. So, for me, everything was a surprise because for some reason I expected something a bit more positive, but then all of this started happening, and I was more and more shocked, and as Eugene said, "disturbed," so [I was] highly disturbed. And so, yeah, it really left me feeling kind of unsettled and, maybe, unsatisfied when I saw this.

It was mentioned that [the movie was based on the] actual book. I really want to read this book now to see what actually her [Miss Jean Brodie's] motivation was because I think we haven't really learned much about her motivation [from the movie]. [In the movie, her motivation] was on [the] very surface, I mean, the level of explanation, - other people [were] talking about that, but Ms. Brodie never admitted anything of this. Like why was she doing this? What was [her own] motivation? Yeah. I'd really like to learn more about that. But overall, the movie was really disturbing, yeah. It raises so many questions and so many uncertainties. Yeah. I have really mixed feelings from our group's discussion. 


\section{The University of Students: A place for joint self-education}

Olga Shugurova, Eugene Matusov, Ana Marjanovic-Shane

Ana: Yeah. [In our group] we were talking about very similar [issues], but we didn't go into the sexist part. We were talking about that fine line between really engaging people's lives so deeply and staying outside of outright manipulation, selfish manipulation, and immoral manipulation. [We also discussed] all that kinds of what you called "listening" or I would call "engaging in other people's deep ontology." [It] opens the door for very abusive manipulation.

[In contrast to the movie,] I had the luck to have a teacher who was very, very charismatic, but she never manipulated us. She really stayed very much on the line to not really take away our possibility to, to, to make good choices for ourselves.

We discussed that the road to hell is [often] paved by good wishes.

Eugene: But I want to ask you guys, is it actually good wishes in the first place?

Ana: That's what we discussed because even fascism itself, uh, people who were fascists, they saw beauty there. They saw culture like [Miss Jean Brodie] does, uh, uh, what's his name, II Duci?

Eugene: Mussolini.

Ana: He came from a very, very [refined] place of Italian culture of art, of passion, of love. All those wishes were, in his eyes, good and, in the eyes of people, who joined him. And they, they fought [for] something they saw good, [for] good wishes. [But] it turned into a monster. [in our group,] we actually were discussing the parallel between fascism and what she's doing in this movie.

So, is it good wishes? Maybe it looks like that to the people who have [these wishes].

Eugene: So, Daria, what you're...

Daria: Um, yeah, it was my point actually about her obsession with perfection. Only it has to do maybe what Olessya - Olessya? [people nod] - said. Uh, what's [Miss Brodie's] motivation? I feel like she looks at her life as [a kind of] canvas, and she wants everything to make sense for her. Like this idea that she parallels herself to Jenny and the way, she wants to replace herself with Jenny because she thinks that it's a beautiful development. And I think everything she does, it's all about this beauty and perfection. She's so cold about it because she doesn't really care about those individual people because they're more like paints for her on this canvas. She, she just really doesn't care. She just can't understand that they're human beings too.

Scott: Yeah. They're like extensions of herself.She's using them, manipulating them, and creating a cult of personality around herself. And I think that a part of the author's intent was to demonstrate how fascism may seem benign. Like there's this person who is progressive and [who is] giving the students all of these wonderful new experiences. And [initially,] she comes across as a very sympathetic character.

In fact, I thought that in particularly... when this movie came out in the sixties, being a sexually open woman and fighting against the system of sexual oppression for women would have made her more sympathetic to the audience. So, you're right. It was the men who were sexually manipulative [in her time] but she was creating this situation where she could still get what she wanted. I thought from that perspective, she was a really sympathetic character.

And then all of a sudden, she starts embracing... well, not all of a sudden, I guess she kind of embraced fascism from the start, but like you see it more and more as it goes on, and you start to question her: her values and what she's been doing from the start. And it is about creating a situation where these girls were loyal to her as opposed to educating them. That's what I thought the premise of the movie was: how fascism can take hold in, in spite of it being this idea of progressivism.

Eugene: Sonia.

Dialogic Pedagogy: An International Online Journal | http://dpj.pitt.edu DOI: 10.5195/dpj.2022.497 | Vol. 10 (2022) 
Sonia: Yeah. I feel like I'm missing a lot from not being able to see the movie. But, I asked Ana earlier, if [the teacher, Miss Brodie was] similar to the music teacher [from the previously watched and discussed Hungarian movie "Sing"], not allowing kids [with imperfect voices] to sing and making them think that they are extremely bad, and she's making them a favor by keeping them there [in a school chorus]. I understood from Ana how this teacher [Miss Brodie] is like; and at that moment, I reflected on the fact that for some years I dreamed to be a progressive educator. And now I see this with totally different eyes. And, um, for example, in my country, progressive education is still something extremely new that some love, but the majority hate [it] because they think [it] is related to conspiracy theories. And, this United States wants to control us. In Romania, we have lots of stereotypes. Yeah.

Scott: Interesting!

Sonia: ... So, [the discussion of this movie] makes me realize how long my journey was and how much I still need to learn. I didn't consider this [before]. [While listening to you] I was writing [your points about progressive education] down. For me, this is an icebreaker. This talk tonight, I do not know the movie, but I'm breaking the ice on my own understanding of some concepts and my own understanding of my dreams. And I'm really [learning] fast [because now] I'm going to something totally, totally different from progressive education that was a big part of my life. So, for me, that was the tricky part, "Knowing the kids inside out gives you power." That was my quote for tonight.

\section{Educationalist Club}

Educationalist Club is an online synchronous zoom space where researchers and practitioners of education discuss problems, excitements, puzzlements, and findings of their research and teaching at any stage of the progress. This Club was originally created by Eugene 20 years ago at the University of Delaware (UD). Initially, it was a "Professional Inquiry Group" (PIG) -- essentially a research group. It consisted of UD faculty and graduate students. Later, it focused on the critical reflections on innovative dialogic and democratic teaching by the participants as well. In the 2010s, the PIG weekly meetings became internationalized afforded by its hybrid, face-to-face, and online (Zoom), nature. In March 2020, due to the Covid-19 pandemic and the University of Delaware lockdown, the weekly PIG meetings became entirely online via Zoom. In fall 2020, the Educationalist Club moved to the University of Students.

Participant's Subjective Perspective: As a new club member, I [Olga Shugurova] come to the Educationalist Club without any preplanned ideas and projects; I come open-hearted and open-minded. So I write from this embodied, situated place of the participant. Perhaps, I am still puzzled by the complex and enigmatic term "educationalist." According to Eugene, the term educationalist involves educators, practitioners of education, (in a very broad sense), and educational researchers. Am I an educationalist? To me, the Club is a dialogic solace of wonder and surprise after a busy, anxious day of working from home during the pandemic. Every time I open our Tuesday 5 PM EST zoom, I enter a different world where everything is unexpected, unpredictable, and unfinalized. This world is what Bakhtin (1984) calls a great dialogue or "an unclosed whole of life itself, life poised on the threshold" (p. 63). This threshold is between the worlds: the past, conventional schooling, the institutional world of suffering, and the future educational, imaginative world of becoming free. What does this freedom mean? I wonder and feel exciting emotions, abstract feelings, unexpected enthusiasm, and the spiritual vulnerability of free learning. How can I talk about being there, in and with this Educationalist Club? I talk from a subjective place of being there when I had just become its member for the first time. I feel as being a stranger, wanderer, speculator who can come and leave at any time without any fear of judgment, punishment, forced obligation, institutional repercussions for absence, or presence. Nevertheless, I feel welcomed as a stranger. As Eugene eloquently explained, the idea of 'stranger' "constitutes civilization and society in contrast to community, family, or kin; it implies respect for the other, rather than the expectation of mutual understanding. It is 
important for a dialogue to happen. A dialogue is based on the idea of strangers, not on the idea of familiarity. The sense of familiarity erases a difference between you and someone else. You almost don't need that person because you can read their mind. This strangeness is very important" (UniS Educationalist Club, May 29, 2021). As Ana explained, strangeness is a "dialogical quality and not a personal quality. In a dialogue, we are suddenly strangers... We drop all other considerations and obligations for that dialogue and become strangers in that dialogue... [Estrangement] is a dialogical concept, rather than a role of a person.

<<Ana, 2021-07-16: Olga asked whether this is actually what I meant. In fact, I am developing an idea that it is possible for a person to assume this kind of a stance of a friendly stranger, for the sake of the dialogue, even with people with whom you are not a stranger in other ways" (UniS Educationalist Club, Jun 23, 2021).>>

Being a stranger inspires curiosity, difference, novelty, spontaneity, imagination, and, consequently, a great dialogue.

The Club is the imaginative threshold between being and becoming. Wegerif et al. (2019) wrote that a dialogue takes place between people and the Infinite Other, "the unbounded horizon. .." (p. 2). As the threshold between worlds, the Club is an open, holistic window onto this horizon, one of many windows into the life of future possibilities and potentials.

I open my zoom; I am late; Eugene, Ana, Brian, A.J., and Olessya are talking. AJ is talking about her future comps and proposal and her interest in non-traditional dissertations. I feel an impulse to jump in and share; I wrote a non-traditional dissertation.

Eugene: Any other advice?

Olga: I don't know if it is a good advice...uh...I did a non-traditional dissertation; It feels like it was yesterday; I was in a similar situation.

Anyway, in my last course, I focused on my proposal, on my vision, of course! I would talk about it all the time, all the time, in class, to process my idea.

[l pause, look at my empty notebook, trying to remember, sip my tea, Thinking about meaning, look at the screen. Everyone is listening]

I would bounce my ideas back and forth with my classmates, my teachers, We had two teachers in our last seminar course: a dialogue about us, researchers. My classmates would ask me: why? What was I getting at? Why was it even significant? My intention was to envision what I was going to do, but it turned out to be very different. I was presetting myself, creating a proposal in my mind. Then, I went into the field, And it turned out to be very different; everything I envisioned had to be put aside, yield To life...

My proposal with all details went onto a shelf, in pieces.

This is when my ethics [IREB] came into place, this process became contested.

So, I guess my advice... 


\section{The University of Students: A place for joint self-education Olga Shugurova, Eugene Matusov, Ana Marjanovic-Shane}

[...]

Eugene: No, no. Can I ask, Olga? Please continue before advice and.. What it turned out to be? It was your plan, right?

Olga: yes, this was the plan.

Eugene: What happened later? Tell us..

Olga: [l hesitate, look at the screen,

Feel touched by the sincere interest in me,

In what happened; Feel reluctant, excited

To share, be free from forced fears

Of speaking back to superiors, to IREB;

Feel for a moment fierce memories,

pulsing in buried words, unasked stories.]

Ok...., - I say in a quiet voice.

[Kindness fills our shared screen]

I'll tell you... secrets,

secrets from being in the field.

So...

[I pause, keep silence, look within

Myself, remembering]

I wanted to do a pilot,

kind of a pilot entry into the field...

Ok, this is...

[l begin to feel my inner tyrant; feel inner tears;

I cover my mouth with my hands, laugh, smile,

Think about my fears ...think again for awhile]

I wanted to talk to people without any formal procedures,

Develop connections, do it informally, go to that region,

Without all these papers that the IREB had given me: thousands,

piles of forms, not thousands, many forms...for the mountains,

for my future participants. . to sign..

I thought, no,

How am I going to do this? I am going to speak to places, strangers...

To people on the street, the Himalayan mountain ranges.

It's like, "Can you sign this paper, then we'll talk?"

No, nobody was going to do this! I was just going to walk... 
off the beaten tracks through the places endangered; nobody knew me there, and I was just a stranger...

All of a sudden, I started speaking with so many people, crowds.

Ok, they were telling me stories, thousands of stories...

In strange places such as bus stops-stones, remote stores,

The people were so interested in me...They asked,

"Why are you doing this at this time? There are no tourists..."

"Why would you come to ask these stupid questions?"

"Maybe the government asked you to do this; so strange."

I said, "no, actually nobody asked me ...I wanted to know."

"Oh, maybe you have the Bible, you are a missioner,

you wanna teach us something...like English?" "No."

....

Then, the IREB told me to STOP...

and to get official permission, certified translations.

This was the end of my ethical, human relations

With local people! The bureaucratic, cruel rupture!

The end of data-collection, my living adventure,

beginning of zombie dread, the institutionalized torture...

Bryan: Basically, ethics made it impossible to do research.

Olga: [l feel Bryan's compassionate truth]

Yes, they ruined it, they ruined my research... uh...ah...

[l breathe, feel pain, past anguish, sigh, search for fresh air...]

In this cumbersome speech flow, I recall my institutional experience of becoming a doctor of philosophy in education. Specifically, I delved into the silenced and subordinated memories of my fieldwork in the Himalayas and the interference of the Institutional Review Ethics Board (IREB) in this intricate, initial research process. I re-create my speech, as I was sharing, remembering my story in the Club. More specifically, I interweave my feelings, emotions, thoughts. In doing so, I represent my speech in a free verse style to invite the reader into my experience of reliving, retelling, remembering this past tragedy. According to Kirkland and Davies (1986), free verse is the easiest of all poetic forms because "it places no real restrictions on the poet; it allows the writer more freedom in choosing words, using sounds, and arranging lines for effect" (p. 76). Likewise, I did not want to place any restrictions on my speech and its representation, so that a sense of freedom and free learning can resonate with the reader as well. Moreover, free verse has an adventurous shape and style of writing that is open to unexpected turns and surprises, spontaneous patterns and unfamiliar repetitions (Andrews, 2017; Dobyns, 2003). Often, I feel like the Educationalist Club itself is a free verse in the making, in becoming, in unfolding meanings. Hence, the spirit of the Club and my spirit of sharing in this Club are free in oral dialogues and in my representational verses of these dialogues. This Club invoked a free spirit of storytelling in me. Also, free verses in and as research "provide 
greater insight into the lived experience of the author" (Willis \& Bishop, 2014, p. 12). In my free verse, I embody the speaking rhythm and spirit, through which I was sharing my experiences without any preplanned structure or objective. I hope that the reader can become a co-participant of my storytelling experience.

Interestingly, I did not plan to share my experience, nor did I plan to mention these layers of secretive meanings about my encounters with the IREB. I was lingering in the zoom threshold of remembering and being in the Club; I felt nebulous feelings of timelessness. I felt like I was in the wilderness, off the grid in a warm log cabin with good people around me, near a dancing fire in a handmade fire pit. When Eugene asked me to share what happened, I felt inspired to share the living truth because everyone seemed to be genuinely interested in listening and hearing me. The Club has this uncanny ambiance of therapeutic healing and recreation, intensity and immediacy. I felt that my speech was an act of self-revelation in the wild spirit of the Club, of being on the threshold between the past, present, and future of learning.

Secretive? I wondered why I thought of these past, schooled, traumatic moments as secretive. I remembered how we were taught to respect and to follow the IREB in all of their questions, forms, and procedures; the IREB was this bastion of official morality and normal righteousness in my mind. In fact, I thought of the IREB as the gatekeeper of good research; without its approval, I could not conduct my field study, I could not proceed further in my learning journey. In reality, the IREB was not a gatekeeper but a gatelock, the lock which was closed off; its keys were kept in the hands of brutal bureaucracy without any human face. Even today I don't know who I was addressing in my communication with the IREB. This board never personally signed any correspondence with their full name, even with their first name. All emails were signed off with an anonymous, mechanical signature "ROMEO system" (i.e., Research Management System). Yet, this faceless Kafkaesque communication was so vital in my research that I spent sleepless nights, agonistic days looking for the right, correct answers to their endless requests for clarifications. I had to obey their demands for official permissions; I had to follow these and abandon my fieldwork completely; I had to become submissive to the oppressive, authoritarian regime of IREB and, consequently, to the government of Nepal, its numerous agencies, ministries. Without these dangerous, life-threatening situations of submissions, I could not obtain any of the permissions. Despite the deep tragedy of the IREB's enforcement of its rules and my dreadful journey of clarifications, I thought I could NOT openly share these abhorrent and absurd experiences in my final dissertation narrative. The template of a PhD dissertation did not have a chapter or a section dedicated to any opposition, resistance, and disagreements with the IREB. I felt it was dangerous even to mention how anti-human and anti-educational they had been to me on my research journey. That is why I decided to silence these traumatic stories in myself and in the final publication of my research. Despite all of the obstacles that were put by the IREB on my research journey, I successfully defended my dissertation and was awarded an unconditional pass for my oral defense in 2017 (Shugurova, 2017).

Why was it even significant to share with researchers all this nonsense, dreadfulness, and real dangers that the IREB had imposed on me? I was the only one to blame, I assumed. Yet, why was I sharing these stories as a novice member of the Educationalist Club? What was I learning? Was I learning or unlearning? What was I learning from talking, from my speech act?

Ana once eloquently said that UniS is the encounter of its students. The Educationalist Club is one of these encounters. To me, the Club is the unstructured, unfinalized, and unregulated space of encounters as free learning. Bakhtin (1999) wrote that Dostoevsky's encounters "always take place. . . 'in infinity' and for 'last time' (in the ultimate moment of crisis), that is, they take place in carnival-mystery play space and time" (p. 177). The Covid-19 pandemic has intensified the moment of a personal crisis of being in this world; 
the Club appeared as the mystery play in infinity and, perhaps, for last time. I felt this sense of infinity in the way the Club is run; everyone can share something without any predetermined, righteous form or normal structure. Everyone has a voice, space, and time to speak. The Club is a genuine dialogue among people who come there to learn and to share. That is why there are infinite possibilities for learning in and through this Club; it is always there, in infinity. I never know who I can speak with and about what; learning never stops there; it is an ever-ending dialogue of life itself. When I think of my being in this Club and my speech about the IREB, Shatov comes to mind in dialogue with Stavrogin in Dostoevsky's The Possessed, "...we are two beings, and have come together in infinity... for the last time in the world. Drop your tone and speak like a human being! Speak, if only, for once in your life, with the voice of a [person, human being]" (as cited in Bakhtin, 1999, p. 177). Likewise, being in the Club feels like this. It inspires me to speak like a human being in infinity, not with a tone but with my voice, the living voice with all of my challenges, weaknesses, struggles. I don't filter my voice through the correct, institutional tone; I speak through my raw voice, mixing languages (Russian, English, Ukrainian, the inaudible hybrid of all of the above). I am no longer worried about my accent, about being misunderstood, being othered. In contrast, the conventional educational institutions force me to speak with a teacher's tone, the all-mighty, the all-knowing tone of an "expert" with the repressed, feared, anxious accent. The Club does not force me to do anything and to be anyone; I am a human being here, I speak like a being in infinity, in encounters with listening, speaking human beings.

I still wonder what was so special about this encounter, this moment of being, in which I was ruminating, remembering all the institutional struggles and battles that I had to suffer in my conventional, institutional learning. These mysterious questions reverberate in my educationalist space of infinity with a new sense of freedom in being human and in free learning.

\section{The current issues, limitations, and challenges for the University of Students}

Currently, we see at least four major obstacles for the University of Students: 1) the civilization of the necessities, 2) colonization of the human spirit by the economy, 3) a lack of genuine leisure, and 4) toxification of the human by foisted education.

\section{The civilization of the necessities}

UniS paves a path to a new, future civilization that is not merely based on imposed necessities and needs, but on free time, dignity, respect, kindness, justice, negative freedom, how things are supposed to be, hopes, inventions, desires, humanness, and, ultimately, love. Interestingly, Sauer (1969) wrote, "The saying that necessity is the mother of invention largely is not true. The needy and miserable societies are not inventive, for they lack the leisure for reflection, experimentation, and discussion" (pp. 20-21). The mother of invention seems to be the surplus over the necessary resources for people -- the surplus that allows those people to imagine, experiment, dialogue, and create.

The civilization based on necessities and anti-human needs has created a miserable society of conventional schooling and institutionalized education, where many people are zombified and alienated from their own desires, goals, talents, learning, being, and becoming to become and act like "smart machines." In contrast, UniS is a leisurely space of reflection, experimentation, and great dialogue. That is why inventions can easily grow and develop in and through diverse UniS spaces, encounters, clubs, events, and moments of enlightenment. UniS students are the authors of this emerging new civilization of innovativeness, creativity, and genuine humanism. Hopefully, UniS becomes a cradle of future civilizations, like the Fertile Crescent of the 21st century. 


\section{The economy}

UniS came into being during the tragic pandemic of Covid-19 and its devastating impacts on people's lives and livelihoods. Ironically, the pandemic has created a possibility for an economic quantum leap to a new system of social sustenance and self-sufficiency. The old economic systems are on the verge or in the process of global collapse (Barlow, van Schalkwyk, McKee, Labonté, \& Stuckler, 2021; Lynch, 2020, June 24; Waitzkin, 2021). Since the beginning of the pandemic, a new system of universal basic income (UBI) has been emerging from the grassroots political organizations, researchers, and the public worldwide. In a nutshell, UBI is a state-based provision of regular income to all citizens regardless of their work, education, and social location (Forget, 2011; Haagh, 2019; Hasdell, 2020). Generally, UBI has 6 main components: 1) universal payment to each and every individuals, rather than specific, target groups; 2) unconditional payments without any requirements or restrictions; 3) cash payments; 4) individual basis rather than households; 5) monthly or periodic payments, rather than once in a lifetime; 6) the sufficient enough amount of the regular payments for a dignified and secure life for each person (Hasdell, 2020; Matusov, 2020b).

According to Forget (2011), UBI recipients improve their mental and physical health as well as invest in education; also, UBI helps people establish successful and meaningful long-term careers and, which is probably more important, dignified and secure life and a possibility for genuine leisure. As Zuckerberg said, "We should have a society that measures progress not just by economic metrics like GDP, but by how many of us have a role we find meaningful. We should explore ideas like universal basic income to make sure everyone has a cushion to try new ideas" (as cited in Forget, 2020, Ch. 4).

However, there are no empirical studies on the significance of UBI to self-educators and the relation of UBI to self-education; hence, future research can fill this gap. At this time, we believe that the UBI and UniS share a commitment to collective self-actualization, self-education, and wellbeing. Also, Forget (2018) found that "in general, people who find the kind of job arrangement that they want are happier than those with full-time employment. Presumably, self-employment gives them the opportunity for greater autonomy and control over their time" (p. 82).

We also believe that UBI will lead to a more meaningful, genuine, creative, and leisurely selfeducation since it is based on personal autonomy and control over one's time and learning. Overall, UBI may serve as a potential economic base for the University of Students.

At the same time, UniS is not connected to any political or economic organization. UniS does not act in favor of any economic regime since it is not governed by economic rationality. UniS students can author and lead their economies any way they see fit.

\section{Genuine leisure}

Often leisure is defined by a person having free time or having a rest to recharge for future work. Many scholars of leisure insist that this is not enough to define the phenomenon of leisure (e.g., de Grazia, 1962; Gorz, 1997; Seabrook, 1989; Veblen, 2007). They argue that leisure is a state of mind in addition to having time free from the person's worries and sickness. In this leisurely state of mind, the active process of doing or being is more important than the products of these activities: "Leisure activities... are pursued as ends in themselves. They are unplanned and unrequired. Leisure is primarily action, directed generally toward self-development" (Atchley, 1971, p. 13). Matusov (2020b) has abstracted at least the following four major forms of leisure: 1) playing, 2) hanging out with friends, 3) hobbies, and 4) intrinsic education. 
People engage in extrinsic education because they value the outcomes of their education much more than its process. Often the participants in extrinsic education want to shorten it as much as possible (Matusov, Baker, Fan, Choi, \& Hampel, 2017). The University of Masters supports mainly extrinsic education while the University of Credits supports exclusively extrinsic education (see above).

In contrast, people engage in intrinsic education because they value the process of their education much more than its outcomes. The participants in intrinsic education do not want to shorten it because they view their intrinsic education as an essential part of their life - shortening education means shortening their life for them (Matusov et al., 2017). Intrinsic education often focuses on promoting creative and/or critical authorship in the students (Matusov, 2020b; Matusov \& Marjanovic-Shane, 2019). Although the University of Students supports both extrinsic and intrinsic education, it is intrinsic education that can flourish at the University of Students.

\section{Detoxification from the conventional schooling of foisted education}

Foisted education of the University of Masters and especially of the University of Credits traumatize students by suppressing, paralyzing, and even robbing them of their authorial agency. Some educators of the democratic school and homeschooling movements (Greenberg, 1991; Llewellyn, 1998; Neill, 1960) have noticed a phenomenon of some students' "toxification" by conventional foisted education. When impositions of education are removed from these students, the students are paralyzed to do anything meaningful to them. They either demand impositions from the adult authority, try to imagine such demands and re-impose the imagined demands on themselves, or do literally nothing -- apparently, suffering from mild or even severe depression. These democratic educators suggest letting students go on these "alienation vacations" (Matusov \& Brobst, 2013) of doing nothing for a while as a necessary process of school detoxification,

When you quit school, do nothing academic for at least, at the absolute minimum, a week. If you wish, however, write stories or journal entries about your past and your future. Dream, dream, dream. If you crave TV, watch it. If you crave sleep, indulge. Allow yourself to go through withdrawal. Pass no judgments. If you want to "work" on anything, work on forgiving and forgetting. Forgive yourself for everything. Forgive your teachers for everything. Forgive your parents for everything. Forget the lies school taught-forget that learning is separate from your life, that you can't teach yourself, that you are defined by your grades, and all other such nonsense. Detoxify. Purge (Llewellyn, 1998, p. 126).

It may take months and even years before full school detoxification and recovery occurs for some students as Neill, the founder of a British democratic school Summerhill, reported in one case: "The recovery time is proportionate to the hatred their last school gave them. Our record case was a girl from a convent. She loafed for three years. The average period of recovery from lesson aversion is three months" (Neill, 1960, p. 2).

Like some democratic schools and homeschooling, the University of Students presents time (patience) and resources for the students' detoxification from foisted education. In contrast to these democratic schools and homeschooling, the University of Students supports autopaternalism as a form of self-education.

\section{Conclusion: The future of the University of Students}

What is the future of UniS? Have we started it at the right historical time? Are we up to the challenge? Will our endeavor succeed, will it be claimed by people, will it overcome the current pressures 
of scarcity, institutionalism, and credentialism? The questions will be answered by those people who find the University of Students helpful for themselves and who join us. And only time will tell, 10, 100 years later or 100 light-years from now.

\section{References}

Andrews, R. (2017). A prosody of free verse : explorations in rhythm. New York: Routledge.

Aristotle. (2000). Nicomachean ethics (R. Crisp, Trans.). Cambridge, UK: Cambridge University Press.

Atchley, R. C. (1971). Retirement and leisure participation: Continuity or crisis? The Gerontologist, 11(1), 13-17.

Bakhtin, M. M. (1999). Problems of Dostoevsky's poetics. Minneapolis: University of Minnesota Press.

Barlow, P., van Schalkwyk, M. C., McKee, M., Labonté, R., \& Stuckler, D. (2021). COVID-19 and the collapse of global trade: building an effective public health response. The Lancet Planetary Health, 5(2), e102-e107.

Berlin, I. (2017). Two concepts of liberty. In D. Miller (Ed.), Liberty Reader (pp. 33-57). New York: Routledge.

Berlin, I., \& Hardy, H. (2002). Freedom and its betrayal: Six enemies of human liberty. Princeton, N.J. Chichester: Princeton University Press.

Bode, C. (1968). The American lyceum: Town meeting of the mind. Carbondale, IL: Southern Illinois University Press.

Caplan, B. D. (2018). The case against education: Why the education system is a waste of time and money. Princeton, $\mathrm{NJ}$ : Princeton University Press.

Cardozier, V. R. (1968). Student power in medieval universities. The Personnel and Guidance Journal, 46(10), 944948.

Carr, W. (2006). Philosophy, methodology and action research. Journal of Philosophy of Education, 40(4), 421-435.

Cobban, A. B. (1980). Student power in the Middle Ages. History Today, 30(2). Retrieved from http://www.historytoday.com/alan-b-cobban/student-power-middle-ages

Dancy, R. M. (1991). Two studies in the early Academy. Albany: State University of New York Press.

de Grazia, S. (1962). Of time work and leisure. New York: The Twentieth Century Fund.

Dobyns, S. (2003). Best words, best order : essays on poetry (2nd ed.). New York: Palgrave Macmillan.

Duberman, M. B. (1969). An Experiment in Education. In M. B. Duberman (Ed.), The uncompleted past (pp. 259-294). New York, NY: Random House.

Duberman, M. B. (2002). Cures: A gay man's odyssey. Boulder, CO: Westview.

Duberman, M. B. (2009). Black Mountain: An exploration in community. Evanston, IL: Northwestern University Press.

Elbow, P. (1971). Exploring my teaching. College English, 32(7), 743-753.

Elbow, P. (1986). Embracing contraries: Explorations in learning and teaching. New York: Oxford University Press.

Forget, E. L. (2011). The town with no poverty: The health effects of a Canadian guaranteed annual income field experiment. Canadian Public Policy, 37(3), 283-305.

Forget, E. L. (2018). Basic income for Canadians: The key to a healthier, happier, more secure life for all. Toronto: James Lorimer \& Company Ltd., Publishers.

Forget, E. L. (2020). Basic Income for Canadians: From the COVID-19 emergency to financial security for all. Toronoto: James Lorimer \& Company.

Gadamer, H. G. (2001). Education is self-education. Journal of Philosophy of Education, 35(4), 529-538.

Gates, L. (2020). Collaborative inquiry: Searching for ways to be a feminist educator in a university context. In K. KeiferBoyd, L. Hoeptner-Poling, S. Klein, W. B. Knight, \& A. P. d. Miles (Eds.), NAEA Women's Caucus LOBBY ACTIVISM: Feminism(s) + Art Education. Reston, VA: National Art Education Association.

Gorz, A. (1997). Farewell to the working class: An essay on post-industrial socialism. London: Pluto Press.

Grant, G., \& Riesman, D. (1978). The perpetual dream: Reform and experiment in the American college. Chicago: University of Chicago Press.

Greenberg, D. (1991). Free at last: The Sudbury Valley School. Framingham, MA: Sudbury Valley School Press.

Grierson, E. M. (2018). Trust and fiduciary relationships in education: What happens when trust is breached? Educational Philosophy and Theory, 50(2), 203-211.

Haagh, L. (2019). The case for universal basic income. Medford, MA: Polity.

Hammersley, M. (1997). Educational research and teaching: A response to David Hargreaves' TTA lecture. British Educational Research Journal, 23(2), 141-161.

Hampel, R. L. (2021). Radical teaching in turbulent times: Martin Duberman's Princeton Seminars, 1966-1970. New York: Palgrave Macmillan. 
Hargreaves, D. H. (1996). Teaching as a research-based profession: Possibilities and prospects. Retrieved from http://www.bera.ac.uk/files/resourcesfiles/educationalresearch/hargreaves 1996.pdf

Hargreaves, D. H. (1997). In defense of research for evidence-based teaching: A rejoinder to Martyn Hammersley. British Educational Research Journal, 23(4), 405-419.

Hasdell, R. (2020). What we know about Universal Basic Income: : A cross-synthesis of reviews. Stanford, CA: Stanford Basic Income Lab.

Holt, J. C. (1972). Freedom and beyond ([1st ed.). New York: E. P. Dutton.

Jones, G. H. (1971). Post mortem: Student-directed courses I and II. College English, 33(3), 284-293.

Jørgensen, M. (1971). Fra Skoleopprør til Opprørsskole. Oslo: PAX FORLAG A/S.

Kant, I. (1784). An answer to the question: What is Enlightenment? Retrieved from https://www.stmarysca.edu/sites/default/files/attachments/files/Kant--What\%20ls\%20Enlightenment .pdf

Kelly, A. (1978). Introduction: A complex vision. In I. Berlin, H. Hardy, \& A. Kelly (Eds.), Russian thinkers (pp. xiii-xxiv). London: Hogarth Press.

Kett, J. F. (1994). The pursuit of knowledge under difficulties: From self-improvement to adult education in America, 1750-1990. Stanford, CA: Stanford University Press.

Kirkland, G., \& Davies, R. (1986). Inside poetry: Teacher's guide. Toronto: Harcourt Brace.

Labaree, D. F. (2010). Someone has to fail: The zero-sum game of public schooling. Cambridge, MA: Harvard University Press.

Lave, J. (1992). Learning as participation in communities of practice. Paper presented at the meeting of the American Educational Research Association, San Francisco, CA.

Llewellyn, G. (1998). The teenage liberation handbook: How to quit school and get a real life and education (Rev., 2nd ed ed.). Eugene, OR: Lowry House.

Lobok, A. M. (2014). Education/obrazovanie as an experience of an encounter. Dialogic Pedagogy: An International Online Journal, 2, S1-S5. doi:10.5195/dpj.2014.84

Lynch, D. J. (2020, June 24). IMF says global economic collapse causes by coronavirus will be even worse than feared. Washington Post. Retrieved from https://www.washingtonpost.com/business/2020/06/24/imf-globaleconomy-coronavirus/

Marjanovic-Shane, A. (2016). "Spoilsport" in drama education vs. dialogic pedagogy. Dialogic Pedagogy: An International Online Journal, 4, A45-A80. doi:10.5195/dpj.2016.151

Marjanovic-Shane, A. (2022, in press-a). A paradigmatic dialogue-disagreement in a democratic school: A conceptual analysis of the soul-searching assembly. Dialogic Pedagogy: An International Online Journal.

Marjanovic-Shane, A. (2022, in press-b). A Soul-Searching Assembly - A Vignette. Dialogic Pedagogy: An International Online Journal.

Marjanovic-Shane, A., Kullenberg, T., \& Gradovski, M. (2022, in press). Scandinavian Experiments in Democratic Education. Dialogic Pedagogy: An International Online Journal.

Martin, T. P. (1987). The sound of our own voices: Women's study clubs 1860-1910. Boston: Beacon Press.

Matusov, E. (2007). Applying Bakhtin scholarship on discourse in education: A critical review essay. Educational Theory, 57(2), 215-237.

Matusov, E. (2011). Irreconcilable differences in Vygotsky's and Bakhtin's approaches to the social and the individual: An educational perspective. Culture \& Psychology, 17(1), 99-119.

Matusov, E. (2015). Legitimacy of non-negotiable imposition in diverse approaches to education. Dialogic Pedagogy: An International Online Journal, 3, A174-A211. Retrieved from http://dpj.pitt.edu/ojs/index.php/dpj1/article/view/110/105

Matusov, E. (2020a). Dialogic analysis of the teacher's pedagogical decision-making in a lesson on the educational controversies of religious holidays in a dialogic multi-regime college classroom. In M. C. Oliveira, A. U. Branco, \& S. F. Freire (Eds.), Psychology as a Dialogical Science: Self and culture mutual development (pp. 29-50). New York: Springer International Publishing.

Matusov, E. (2020b). Envisioning education in a post-work leisure-based society: A dialogic perspective. New York: Palgrave.

Matusov, E. (2020c). A student's right to freedom of education and a teacher's fiduciary obligation to support it: Reply to the commentaries. Dialogic Pedagogy: An International Online Journal, 8, SF97-SF114. doi:10.5195/dpj.2020.357 


\section{The University of Students: A place for joint self-education}

Olga Shugurova, Eugene Matusov, Ana Marjanovic-Shane

Matusov, E. (2020d). A student's right to freedom of education. Dialogic Pedagogy: An International Online Journal, 8, SF1-SF28. doi:10.5195/dpj.2020.356

Matusov, E. (2021a). Progressive education is the opium of the educators. Integrative Psychological and Behavioral Science, 1-34.

Matusov, E. (2021b). The relationship between education and learning and its consequences for dialogic pedagogy. Dialogic Pedagogy: An International Online Journal, 9, E1-E19.

Matusov, E. (2021c). Teacher as a benevolent dictator. In R. L. Hampel (Ed.), Radical Teaching in Turbulent Times: Martin Duberman's Princeton Seminars, 1966-1970 (pp. 207-226). New York: Palgrave Macmillan.

Matusov, E. (2022, in press). Democracy, dialogism, therapy, progressivism, anarchism, and other values in Martin Duberman's innovative pedagogy. Dialogic Pedagogy: An International Online Journal.

Matusov, E. (2022, submitted). The teachers' pedagogical fiduciary duty to their students. Educational Practice \& Theory.

Matusov, E., Baker, D., Fan, Y., Choi, H. J., \& Hampel, R. L. (2017). Magic Learning Pill: Ontological and instrumental learning in order to speed up education. Integrative Psychological and Behavioral Science, 51(3), 456-476. doi:10.1007/s12124-017-9384-8

Matusov, E., \& Brobst, J. (2013). Radical experiment in dialogic pedagogy in higher education and its centaur failure: Chronotopic analysis. Hauppauge, NY: Nova Science Publishers.

Matusov, E., \& Marjanovic-Shane, A. (2015). Typology of critical dialogue and power relations in Democratic Dialogic Education. In K. Jezierska \& L. Koczanowicz (Eds.), Democracy in dialogue, dialogue in democracy (pp. 211229). Farnham, UK: Ashgate Publishing, Ltd.

Matusov, E., \& Marjanovic-Shane, A. (2019). Intrinsic education and its discontents. In L. Tateo (Ed.), Educational dilemmas: A cultural psychological perspective (pp. 21-40). New York: Routledge.

Matusov, E., Marjanovic-Shane, A., \& Meacham, S. (2016). Pedagogical voyeurism: Dialogic critique of documentation and assessment of learning. International Journal of Educational Psychology, 5(1), 1-26. doi:10.17583/ijep.2016.1886

Matusov, E., Smith, M. P., Soslau, E., Marjanovic-Shane, A., \& von Duyke, K. (2016). Dialogic education from and for authorial agency. Dialogic Pedagogy: An International Online Journal, 4, A162-A197. doi:10.5195/dpj.2016.172

Mouffe, C. (2000). The democratic paradox. London: Verso.

Neill, A. S. (1960). Summerhill: A radical approach to child rearing. New York: Hart Publishing Company.

Nikulin, D. V. (2010). Dialectic and dialogue. Stanford, CA: Stanford University Press.

Pettit, P. (2014). Just freedom: A moral compass for a complex world (First Edition. ed.). New York: W.W. Norton \& Company.

Phillips, C. (2002). Socrates café: A fresh taste of philosophy. New York: W.W. Norton.

Phillips, C. (2011). Constitution cafe: Jefferson's brew for a true revolution (1st ed.). New York: W. W. Norton \& Co.

Plato. (1997). Complete works (J. M. Cooper \& D. S. Hutchinson, Trans.). Indianapolis, IN: Hackett Pub.

Rancière, J. (2004). Introducing disagreement. Angelaki: Journal of the Theoretical Humanities, 9(3), 3-9.

Reti, I., Vanderscoff, C., \& Rabkin, S. (2020). Seeds of something different: An oral history of the University of California, Santa Cruz. Santa Cruz, CA: University of California, Santa Cruz, University Library.

Rousseau, J. J. (1979). Emile: or, On education. New York: Basic Books.

Rumel, J. E. (2013). Back to the future: The in loco parentis doctrine and its impact on whether K-12 schools and teachers owe a fiduciary duty to students. Indiana Law Review, 46(3), 711-751.

Sauer, C. O. (1969). Agricultural origins and dispersals; the domestication of animals and foodstuffs (2d ed.). Cambridge, MA: M.I.T. Press.

Seabrook, J. (1989). The leisure society. New York: Basil Blackwell.

Shor, I. (1996). When students have power: Negotiating authority in a critical pedagogy. Chicago: University of Chicago Press.

Shor, I., Matusov, E., Marjanovic-Shane, A., \& Cresswell, J. (2017). Dialogic \& Critical Pedagogies: An Interview with Ira Shor. Dialogic Pedagogy: An International Online Journal, 5, S1-S21. doi:10.5195/dpj.2017.208

Shugurova, O. (2017). Learning, local knowledge and place: A historical perspective on educational sustainability before the advent of compulsory schooling in Tibet. (PhD Doctoral dissertation). Nipissing University, Retrieved from https://artography.edcp.educ.ubc.ca/wpcontent/uploads/2017/07/ShugurovaDissertation2017.-1.pdf 


\section{The University of Students: A place for joint self-education}

Olga Shugurova, Eugene Matusov, Ana Marjanovic-Shane

Shugurova, O. (2019). Teaching teacher candidates about social transformations through arts and place:" Wait, but what does it have to do with me as a teacher?". Inquiry in education, 11(1), 1-19.

Sidorkin, A. M. (2009). Labor of learning: Market and the next generation of education reform. Rotterdam, the Netherlands: Sense Publishers.

Tompkins, J. P. (1996). A life in school: What the teacher learned. Reading, MA: Addison-Wesley Pub. Co.

Valley, G. E., Jr. (1974). My years in the MIT Experimental Study Group: Some old facts and new myths. Retrieved from https://www.mit.edu/ irising/webres/myyears.pdf

Veblen, T. (2007). The theory of the leisure class. New York: Oxford University Press Inc.

Vygotsky, L. S., \& Kozulin, A. (1986). Thought and language (Translation newly rev. and edited / ed.). Cambridge, MA: MIT Press.

Waitzkin, H. (2021). COVID-19 as Cause versus Trigger for the Collapse of Capitalism. International Journal of Health Services, 51(2), 203-205.

Wegerif, R., Doney, J., Richards, A., Mansour, N., Larkin, S., \& Jamison, I. (2019). Exploring the ontological dimension of dialogic education through an evaluation of the impact of Internet mediated dialogue across cultural difference. Learning, Culture and Social Interaction, 20, 80-89.

Wenger, E. (1998). Communities of practice: Learning, meaning, and identity. Cambridge, UK: Cambridge University Press.

Willis, K., \& Bishop, E. (2014). " Hope is that fiery feeling": Using Poetry as Data to Explore the Meanings of Hope for Young People. Forum: Qualitative Social Research, 15(1), 1-19.

Winslow, H. M. (1912). The modem club woman. The Delineator, 80(6), 127.

Xenophon. (1994). Memorabilia. London: Cornell University Press.

\section{$(\mathrm{cc}) \mathrm{Br}_{\mathrm{Br}}$}

New articles in this journal are licensed under a Creative Commons Attribution 4.0 United States License.

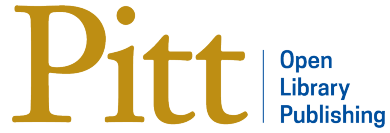

This journal is published by Pitt Open Library Publishing. 